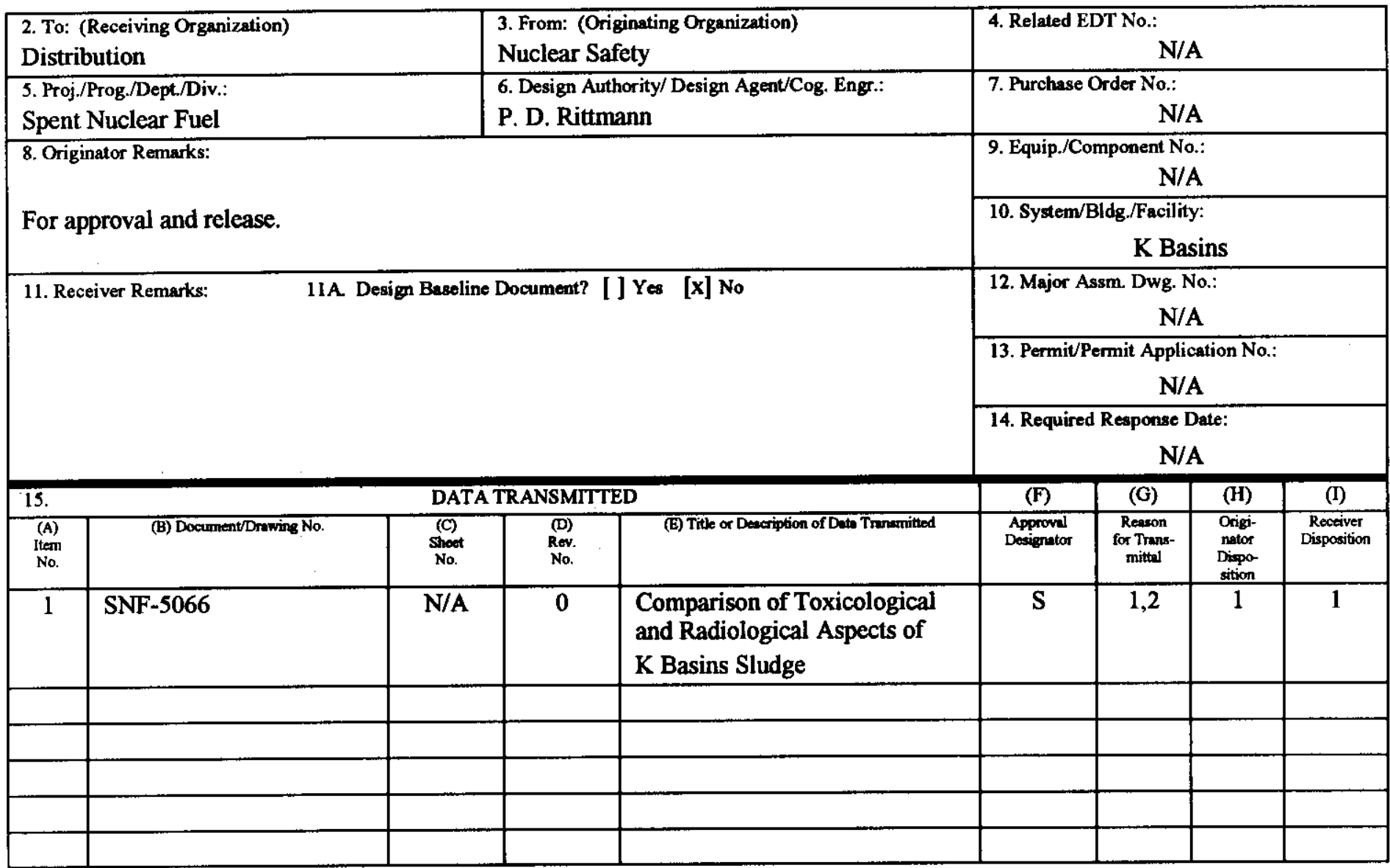

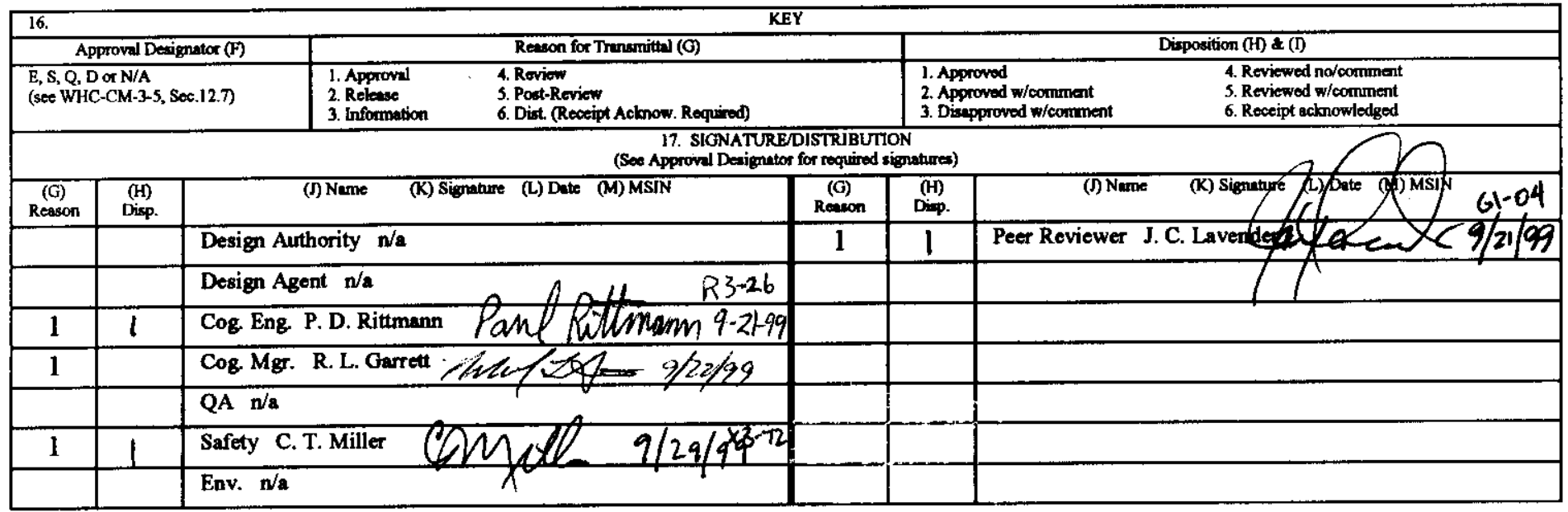

\begin{tabular}{|c|c|c|c|c|c|}
\hline 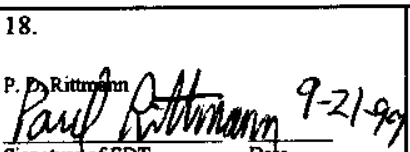 & $\begin{array}{l}19 . \\
\text { n/2 }\end{array}$ & & 20. & $9 / 2,98$ & $\begin{array}{l}\text { 21. DOE APPROVAL (if required) } \\
\text { Ctrl. No. } \\
\text { [] Approved } \\
\text { [] Approved w/comments }\end{array}$ \\
\hline $\begin{array}{l}\text { Signaturetof EDT } \\
\text { Originator }\end{array}$ & $\begin{array}{l}\text { Authorized Representutive } \\
\text { for Rectiving Orgenization }\end{array}$ & $\overline{\text { Date }}$ & $\begin{array}{l}\text { Desigen Authonty } \\
\text { Cognizant Manager }\end{array}$ & & \\
\hline
\end{tabular}

BD-7400-172-2 (05/96) GEF097 


\section{Comparison of Toxicological and Radiological Aspects of K Basins Sludge}

P. D. Rittmann

Fluor Daniel Hanford, Inc., Richland, WA 99352

U.S. Department of Energy Contract DE-ACO6-96RL13200

EDT: 626895

Org Code: 2F200

UC: 920

B\&R Code: EW31354040

Charge Code: $105414 / \mathrm{CB} 80$

Total Pages: 51

Key Words: K Basin, toxicological, radiological, airborne

Abstract: The composition of various $\mathrm{K}$ Basins sludge is evaluated for its toxicological and radiological impacts downwind from accidents. It is shown that the radiological risk evaluation guidelines are always more limiting than the toxicological risk evaluation guidelines.

TRADEMARK DISCLAIMER. Reference herein to any specific commercial product, process, or service by trade name, trademark, manufacturer, or otherwise, does not necessarily constitute or imply its endorsement, recommendation, or favoring by the United States Government or any agency thereof or its contractors or subcontractors.

Printed in the United States of America. To obtain copies of this document, contact: Doctument Control Services, P.O. Box 950, Mailstop H6-08, Richland WA 99352, Phone (509) 372-2420; Fax (509) 376,Anso
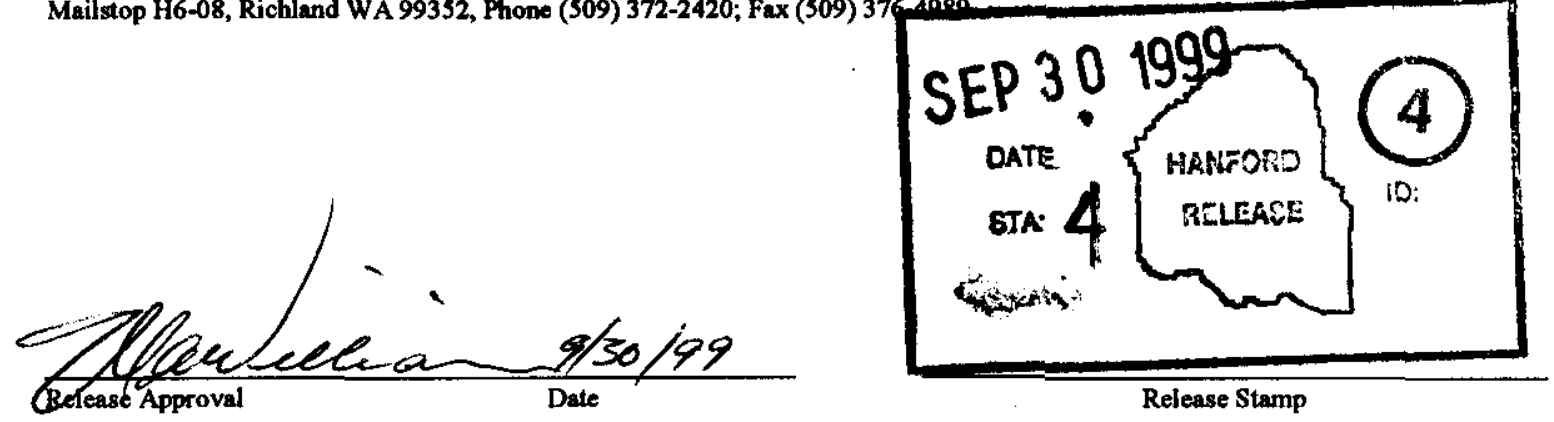


\section{Comparison of Toxicological and Radiological Aspects of K-Basins Sludge} by Paul D. Rittmann, PhD CHP

The sludge at $K$ basins contains more than just radioactive material. It also contains a variety of potentially toxic chemicals. DOE-RL has provided risk acceptance guidelines for both. For evaluation of accident consequences, it can be shown that the radiological doses are substantially closer to these guidelines than are the toxicological air concentrations.

The approach followed in this report is very similar to that followed in HNF-SD-SNF-TI-059. First, the composition of $K$ basins sludge is described. Second, concentration-weighted risk guidelines (CWRG) are computed. Finally, the radiological and the toxicological consequences of postulated accidents are compared using a ratioing approach in which doses and air concentrations are divided by the corresponding DOE-RL guidance. It is shown that the radiological guidelines are always more limiting than the toxicological guidelines. For this reason, the accident analyses need only examine the radiological effects. The peer review checklist is included as Appendix $A$.

The DOE-recommended risk evaluation guidelines (Sellers 1997) for radiological consequences and for toxicological exposures are shown in Tables 1 and 2 below.

Table 1. Radiological Risk Evaluation Guidelines for the Spent Nuclear Fuel Project.

\begin{tabular}{|c|c|c|}
\hline Frequency & Onsite & Offsite \\
\hline Anticipated & $1.0 \mathrm{rem}$ & $0.5 \mathrm{rem}$ \\
$10^{+0}$ to $10^{-2} / \mathrm{yr}$ & $(0.01 \mathrm{~Sv})$ & $(0.005 \mathrm{~Sv})$ \\
\hline Unlikely & $10 \mathrm{rem}$ & $5.0 \mathrm{rem}$ \\
$10^{-2}$ to $10^{-4} / \mathrm{yr}$ & $(0.1 \mathrm{~Sv})$ & $(0.05 \mathrm{~Sv})$ \\
\hline Extremely unlikely & $25 \mathrm{rem}$ & $5.0 \mathrm{rem}$ \\
$10^{-4}$ to $10^{-6} / \mathrm{yr}$ & $(0.25 \mathrm{~Sv})$ & $(0.05 \mathrm{~Sv})$ \\
\hline
\end{tabular}

$1 \mathrm{sv}=100 \mathrm{rem}$

The doses are 50 year committed effective dose equivalents.

Onsite values are "risk evaluation guidelines", while offsite values are "accident release limits" (Sellers 1997). 
Table 2. Toxicological Air Concentration Guidelines for the Spent Nuclear Fuel Project.

\begin{tabular}{|c|c|c|}
\hline Frequency & Onsite & Offsite \\
\hline $\begin{array}{r}\text { Anticipated } \\
10^{+0} \text { to } 10^{-2} / \mathrm{yr}\end{array}$ & $\leq$ ERPG-1 & $\leq$ PEL-TWA \\
\hline $\begin{array}{r}\text { Unlikely } \\
10^{-2} \text { to } 10^{-4} / \mathrm{yr}\end{array}$ & $\leq$ ERPG-2 & $\leq$ ERPG-1 \\
\hline $\begin{array}{r}\text { Extremely unlikely } \\
10^{-4} \text { to } 10^{-6} / \mathrm{yr}\end{array}$ & $\leq$ ERPG-3 & $\leq$ ERPG-2 \\
\hline
\end{tabular}

ERPG = emergency response planning guidel ine.

PEL = permissible exposure limit.

TWA $=$ time-weighted average.

The following are definitions for ERPGs and the PEL-TWA (AIHA 1991).

- The ERPG-1 value is the maximum airborne concentration to which it is believed that nearly all individuals could be exposed for up to 1 hour without experiencing other than mild transient adverse health effects or perceiving a clearly defined objectionable odor.

- The ERPG-2 value is the maximum airborne concentration to which it is believed that nearly all individuals could be exposed for up to 1 hour without experiencing or developing irreversible or other serious health effects or symptoms that could impair their abilities to take protective action.

- The ERPG-3 value is the maximum airborne concentration to which it is believed that nearly all individuals could be exposed for up to 1 hour without experiencing or developing life-threatening health effects.

- The PEL-TWA value is the employees' average airborne exposure in any 8-hour work shift of a 40-hour work week that shall not be exceeded.

PEL-TWA use for emergency response is not strictly appropriate because the PEL-TWA is designed to control relatively long-term worker exposure rather than the short term exposure to the public that would be expected for accident response. The lower of the ERPG-l and the PEL-TWA should be used for the offsite exposure for high frequency events. Use of the limits that are at or below the ERPG-1 accident category provides an additional level of conservatism. However, it will be shown that radiological effects are more important than toxicological effects, so this refinement is not needed.

No published ERPG values exist for a number of chemicals found in sludge. Therefore ERPG values developed by craig to fill these gaps were employed (Craig 1997). These interim ERPG values are known as temporary emergency exposure limits or TEELs. Values for compounds that have been found in $\mathrm{K}$ basins sludge are listed in Table 3 below. In addition, values for 
plutonium and americium are assumed to be the same as those for uranium. This assumption has no effect on the conclusions, but illustrates how little these elements contribute to the overall toxicity of the mixtures.

Table 3. Air Concentration Guidelines for Sludge Chemicals

\begin{tabular}{|c|c|c|c|c|}
\hline Analyte & PEL-TWA & ERPG-1 & ERPG-2 & ERPG-3 \\
\hline $\mathrm{Ag}_{2} \mathrm{O}$ & 0.01 & 0.3 & 0.5 & 10 \\
\hline $\mathrm{Al}_{2} \mathrm{O}_{3}$ & 10 & 15 & 15 & 25 \\
\hline$A m$ & 0.05 & 0.6 & 0.6 & 10 \\
\hline $\mathrm{B}_{2} \mathrm{O}_{3}$ & 10 & 30 & 50 & 250 \\
\hline $\mathrm{BaO}$ & 0.5 & 1.5 & 2.5 & 12.5 \\
\hline $\mathrm{BeO}$ & 0.002 & 0.01 & 0.025 & 0.1 \\
\hline $\mathrm{BiO}$ & NA & NA & NA & NA \\
\hline $\mathrm{CO}$ & 39.9 & 228 & 399 & 570 \\
\hline $\mathrm{CaO}$ & 5 & 6 & 10 & 25 \\
\hline $\mathrm{CdO}$ & 0.005 & 0.03 & 4 & 9 \\
\hline $\mathrm{Cr}_{2} \mathrm{O}_{3}$ & 0.5 & 1.5 & 2.5 & 25 \\
\hline CuO & 1 & 3 & 5 & 100 \\
\hline $\mathrm{Fe}_{2} \mathrm{O}_{3}$ & 10 & 15 & 25 & 2500 \\
\hline $\mathrm{MgO}$ & 10 & 30 & 50 & 250 \\
\hline $\mathrm{MnO}_{2}$ & 0.2 & 3 & 5 & 500 \\
\hline $\mathrm{Na}_{2} \mathrm{O}$ & 10 & 30 & 50 & 250 \\
\hline $\mathrm{NiO}$ & 1 & 3 & 5 & 20 \\
\hline $\mathrm{PO}_{3}$ & 1 & 3 & 100 & 500 \\
\hline $\mathrm{PbO}$ & 0.05 & 0.15 & 0.25 & 100 \\
\hline $\mathrm{Pu}$ & 0.05 & 0.6 & 0.6 & 10 \\
\hline $\mathrm{Se}$ & 0.2 & 0.6 & 1 & 1 \\
\hline $\mathrm{SiO}_{2}$ & 0.1 & 0.3 & 0.5 & 25 \\
\hline $\mathrm{Sm}_{2} \mathrm{O}_{3}$ & NA & NA & NA & NA \\
\hline $\mathrm{Sr}$ & 10 & 30 & 50 & 500 \\
\hline $\mathrm{Tl}_{2} \mathrm{O}_{3}$ & 2 & 2 & 2 & 20 \\
\hline UO & 0.05 & 0.6 & 0.6 & 10 \\
\hline Zno & 10 & 15 & 15 & 500 \\
\hline $\mathrm{ZrO}_{2}$ & 5 & 10 & 25 & 50 \\
\hline PCB & 0.001 & 0.003 & 0.005 & 500 \\
\hline
\end{tabular}

The air concentration guidelines are given in units of $\mathrm{mg} / \mathrm{m}^{3}$. Values are from Craig 1997. Values for Am and Pu are assumed to be the same as vo. The assumed compounds are from HNF-SD-SNF-TI-009 volume 2. 


\section{Composition of $K$ Basins Sludge}

In HNF-SD-SNF-TI-009 Volume 2, sludge characterization is presented for several locations ranging from the basin floor to fuel washing. For convenience, two broad categories will be used in this report, (1) the general sludge associated with material on the basin and pit floors, and (2) the canister sludge associated with the canisters and fuel washing. Sludge volumes are much larger in KE than KW, thus more characterization data exists for KE. In particular, the general sediments in KE basin have been analyzed, while that in $\mathrm{KW}$ has not. It is assumed that the composition of the $\mathrm{KW}$ general sludge is bounded by that found in KE. Canister sludges for both basins have been analyzed.

The average composition of KE basin general sludge is given in Table 4. This composition is assumed for both KE and KW Basin (HNF-SD-SNF-TI-009 Volume 2) except that KW has no PCBs. The composition was determined using a method that quantifies the elements without identifying chemical compounds. The assumed chemical forms are oxides, except for PCBS. The additional mass associated with the oxides were included in the values listed in HNF-SD-SNF-TI-009.

The mass densities of americium (Am) and strontium ( $\mathrm{Sr}$ ) shown in Table 4 are calculated from the radiological composition. The calculation first multiplies the activity concentration $(\mu \mathrm{C} \mathrm{i} / \mathrm{g})$ by the dry density $(\mathrm{g} / \mathrm{cc})$ to convert the activity concentration to volume units $(\mu \mathrm{Ci} / \mathrm{Cc})$. Then the activity per unit volume is divided by the specific activity of the isotope to obtain the mass densities shown in Table 4. Values for specific activities are shown in the notes to Table 4. In all cases, the mass density associated with the isotopes is an insignificant addition to the total mass as well as the chemical toxicity of the mixture. The mass of $\mathrm{Cs}-137$ was not calculated because no air concentration guidelines exist for cesium compounds based on toxicological considerations. The plutonium mass was not calculated because it is given in HNF-SD-SNF-TI-009 Volume 2.

Note that the radioactive composition of $K$ basins sludge that is used for safety basis calculations is the bounding SNF composition as stated in HNF-SD-SNF-TI-009 Volume 2, Section 3.5. The bounding composition has the most conservative value for inhalation dose per unit mass inhaled, or unit dose (UD).

The dry density and wet density of the settled material are shown in Table 4. The dry density is used to covert the radiological composition from activity per unit mass to activity per unit volume. The volumes of sludge shown in Table 4 are those estimated for KE Basin. The KW Basin volumes are much smaller.

Characterization data for the KE Basin includes only the "Main Basin Floor", the "Weasel Pit", the "North Loadout Pit", and a few canisters. Compositions for the "Tech View Pit" and "Elevator Pit" are assumed to be bounded by the sludge composition of the "Weasel Pit", and are therefore not shown. 
In the absence of characterization data for the $\mathrm{KW}$ basin, it is assumed that the sludge composition is the same as in KE (Table 4), except that KW has no PCBS (HNF-SD-SNF-TI-009). For KW the composition of the "Discharge Chute" is also assumed to have the same composition as the "Wease] Pit".

The comparison between radiological and toxicological risk of the sludge mixtures depends entirely on the relative amounts of the chemicals in each type of sludge. Thus the cases where the same composition is assumed will also have the same comparison ratio between radiological and toxicological risk.

Table 4. KE Basin General Sludge Composition (2 pages)

\begin{tabular}{|c|c|c|c|c|c|}
\hline Analyte & Weasel Pit & $\begin{array}{c}\text { Main Basin } \\
\text { Floor }\end{array}$ & $\begin{array}{c}\text { Tech View } \\
\text { Pit }\end{array}$ & $\begin{array}{c}\text { North } \\
\text { Loadout Pit }\end{array}$ & $\begin{array}{c}\text { Elevator } \\
\text { Pit }\end{array}$ \\
\hline \multicolumn{6}{|c|}{ Mass Densities $(g / c c)$ of KE Basin Sludges } \\
\hline $\mathrm{Ag}_{2} \mathrm{O}$ & 0.000017 & 0.000007 & 0.000017 & nd & 0.000017 \\
\hline $\mathrm{Al}_{2} \mathrm{O}_{3}$ & 0.062895 & 0.041372 & 0.062895 & 0.014103 & 0.062895 \\
\hline $\mathrm{Am}$ & 0.000022 & 0.000066 & 0.000022 & 0.000005 & 0.000022 \\
\hline $\mathrm{B}_{2} \mathrm{O}_{3}$ & 0.000406 & 0.000303 & 0.000406 & nd & 0.000406 \\
\hline $\mathrm{BaO}$ & 0.000379 & 0.000111 & 0.000379 & 0.000065 & 0.000379 \\
\hline $\mathrm{Be} 0$ & 0.000045 & 0.000052 & 0.000045 & 0.000016 & 0.000045 \\
\hline $\mathrm{BiO}$ & nd & nd & nd & nd & nd \\
\hline $\mathrm{CO}$ & 0.007600 & 0.006030 & 0.007600 & nd & 0.007600 \\
\hline $\mathrm{CaO}$ & 0.015968 & 0.003087 & 0.015968 & 0.003699 & 0.015968 \\
\hline $\mathrm{CdO}$ & 0.000050 & 0.000060 & 0.000050 & 0.000051 & 0.000050 \\
\hline $\mathrm{Cr}_{2} \mathrm{O}_{3}$ & 0.001333 & 0.000303 & 0.001333 & 0.000122 & 0.001333 \\
\hline $\mathrm{CuO}$ & 0.000433 & 0.000289 & 0.000433 & 0.000239 & 0.000433 \\
\hline $\mathrm{Fe}_{2} \mathrm{O}_{3}$ & 0.403050 & 0.128683 & 0.403050 & 0.037761 & 0.403050 \\
\hline MgO & 0.002863 & 0.001052 & 0.002863 & 0.000622 & 0.002863 \\
\hline MnO & 0.000583 & 0.000245 & 0.000583 & 0.000323 & 0.000583 \\
\hline $\mathrm{Na}_{2} \mathrm{O}$ & 0.000966 & 0.001533 & 0.000966 & nd & 0.000966 \\
\hline $\mathrm{NiO}$ & nd & nd & nd & nd & nd \\
\hline $\mathrm{PO}_{3}$ & nd & nd & nd & nd & nd \\
\hline $\mathrm{Pb0}$ & 0.000475 & 0.000183 & 0.000475 & 0.000105 & 0.000475 \\
\hline $\mathrm{Pu}$ & 0.000076 & 0.000102 & 0.000076 & 0.000060 & 0.000076 \\
\hline $\mathrm{Se}$ & 0.000173 & 0.000063 & 0.000173 & nd & 0.000173 \\
\hline $\mathrm{SiO}_{2}$ & 0.235325 & 0.073942 & 0.235325 & 0.297060 & 0.235325 \\
\hline
\end{tabular}


Table 4. KE Basin General Sludge Composition (2 pages)

\begin{tabular}{|c|c|c|c|c|c|}
\hline Analyte & Weasel Pit & $\begin{array}{c}\text { Main Basin } \\
\text { Floor }\end{array}$ & $\begin{array}{c}\text { Tech View } \\
\text { Pit }\end{array}$ & $\begin{array}{c}\text { North } \\
\text { Loadout Pit }\end{array}$ & $\begin{array}{c}\text { Elevator } \\
\text { Pit }\end{array}$ \\
\hline $\mathrm{Sm}_{2} \mathrm{O}_{3}$ & 0.000201 & 0.000073 & 0.000201 & 0.000042 & 0.000201 \\
\hline $\mathrm{Sr}$ & 0.000015 & 0.000018 & 0.000015 & nd & 0.000015 \\
\hline $\mathrm{T}_{2} \mathrm{O}_{3}$ & 0.000344 & 0.000136 & 0.000344 & 0.000105 & 0.000344 \\
\hline UO & 0.063422 & 0.038469 & 0.063422 & 0.015223 & 0.063422 \\
\hline $\mathrm{ZnO}$ & 0.001168 & 0.000436 & 0.001168 & nd & 0.001168 \\
\hline $\mathrm{ZrO}_{2}$ & 0.000673 & 0.000224 & 0.000673 & nd & 0.000673 \\
\hline PCB & 0.000225 & 0.000083 & 0.000225 & nd & 0.000225 \\
\hline Other & 0.062079 & 0.056651 & 0.062079 & nd & 0.062079 \\
\hline Total: & 0.86079 & 0.35357 & 0.86079 & 0.36960 & 0.86079 \\
\hline Dry Density: & 0.931 & 0.375 & 0.931 & 0.370 & 0.931 \\
\hline Wet Density: & 1.56 & 1.32 & 1.56 & 1.27 & 1.56 \\
\hline \multicolumn{6}{|c|}{ Miscellaneous Characteristics of KE Basin Sludges } \\
\hline Volume, $\mathrm{m}^{3}:$ & 10.10 & 21.50 & 0.40 & 6.30 & 1.40 \\
\hline Volume, L: & 10,100 & 21,500 & 400 & 6,300 & 1,400 \\
\hline Wet Sludge, MT: & 15.76 & 28.38 & 0.62 & 8.00 & 2.18 \\
\hline Dry S1udge, MT: & 9.40 & 8.06 & 0.37 & 2.33 & 1.30 \\
\hline Uranium, kg: & 559.83 & 722.84 & 22.17 & 83.87 & 77.6 \\
\hline \multicolumn{6}{|c|}{ Radiological Composition $(\mu \mathrm{Ci} / \mathrm{g})$ of KE Basin Sludges } \\
\hline Sr-90 & 223.55 & 302.20 & 223.55 & 0.00 & 223.55 \\
\hline Cs-137 & 293.54 & 310.24 & 293.54 & 37.84 & 293.54 \\
\hline $\mathrm{Pu}-239$ & 5.37 & 19.88 & 5.37 & 10.05 & 5.37 \\
\hline$A m-241$ & 8.17 & 28.11 & 8.17 & 7.27 & 8.17 \\
\hline
\end{tabular}

Notes: Listed data comes from HNF-SD-SNF-TI-009 Rev 2. Data not given in the document is indicated by "nd". The specific activities needed to convert activity into mass for an isotope are listed below.

$\begin{array}{ll}\text { Sr-90: } & 139.03 \mathrm{ci} / \mathrm{g} \\ \text { Cs-137: } & 86.55 \mathrm{ci} / \mathrm{g} \\ \text { Pu-239: } & 0.06197 \mathrm{Ci} / \mathrm{g} \\ \text { Am-241: } & 3.4314 \mathrm{ci} / \mathrm{g}\end{array}$

$\begin{array}{ll}\text { Pu-239: } & 0.06197 \mathrm{Ci} / \mathrm{g} \\ \text { Ann-241: } & 3.4314 \mathrm{Ci} / \mathrm{g}\end{array}$

Compositions for the "Tech View Pit" and "Elevator Pit" are assumed to be bounded by the composition measured for the "Weasel Pit". 
Table 5. KE Basin Canister and Fuel Sludge Composition (2 pages)

\begin{tabular}{|c|c|c|c|c|c|}
\hline \multirow{2}{*}{ Analyte } & \multicolumn{2}{|c|}{ Canister Sludge } & \multicolumn{3}{|c|}{ Fuel Washing Sludge } \\
\hline & Fu11 & Empty & Internal & Coating & Pieces \\
\hline \multicolumn{6}{|c|}{ Mass Densities $(\mathrm{g} / \mathrm{cc})$ of KE Basin Sludges } \\
\hline $\operatorname{Ag} 20$ & 0.000094 & 0.000094 & nd & nd & nd \\
\hline $\mathrm{Al}_{2} \mathrm{O}_{3}$ & 0.170042 & 0.170042 & 0.025395 & 0.213762 & nd \\
\hline $\mathrm{Am}$ & 0.000107 & 0.000107 & 0.000073 & 0.000002 & 0.000077 \\
\hline $\mathrm{B}_{2} \mathrm{O}_{3}$ & 0.000939 & 0.000939 & nd & nd & nd \\
\hline $\mathrm{BaO}$ & 0.000162 & 0.000162 & nd & nd & nd \\
\hline $\mathrm{BeO}$ & 0.000198 & 0.000198 & nd & nd & nd \\
\hline BiO & 0.000413 & 0.000413 & nd & nd & nd \\
\hline $\mathrm{CO}$ & 0.009904 & 0.009904 & 0.007600 & nd & 0.007600 \\
\hline $\mathrm{CaO}$ & 0.001624 & 0.001624 & nd & 0.014884 & nd \\
\hline $\mathrm{CdO}$ & 0.000084 & 0.000084 & nd & nd & nd \\
\hline $\mathrm{Cr}_{2} \mathrm{O}_{3}$ & 0.000577 & 0.000577 & nd & nd & nd \\
\hline CuO & 0.000481 & 0.000481 & nd & nd & nd \\
\hline $\mathrm{Fe}_{2} \mathrm{O}_{3}$ & 0.109399 & 0.109399 & 0.004348 & 0.028622 & nd \\
\hline $\mathrm{MgO}$ & 0.002350 & 0.002350 & nd & nd & nd \\
\hline $\mathrm{MnO}$ & 0.000456 & 0.000456 & nd & nd & nd \\
\hline $\mathrm{Na}_{2} \mathrm{O}$ & 0.000806 & 0.000806 & nd & nd & nd \\
\hline $\mathrm{NiO}$ & 0.000253 & 0.000253 & nd & nd & nd \\
\hline $\mathrm{PO}_{3}$ & 0.002017 & 0.002017 & nd & nd & nd \\
\hline Pb0 & 0.000413 & 0.000413 & nd & nd & nd \\
\hline $\mathrm{Pu}$ & 0.001536 & 0.001536 & 0.008681 & 0.001794 & 0.033569 \\
\hline $\mathrm{Se}$ & nd & nd & nd & nd & nd \\
\hline $\mathrm{SiO}_{2}$ & 0.039261 & 0.039261 & 0.348580 & nd & nd \\
\hline $\mathrm{Sm}_{2} \mathrm{O}_{3}$ & nd & nd & nd & nd & nd \\
\hline $\mathrm{Sr}$ & 0.000020 & 0.000020 & 0.000033 & 0.000001 & 0.000046 \\
\hline $\mathrm{Tl}_{2} \mathrm{O}_{3}$ & nd & nd & nd & nd & nd \\
\hline UO & 0.531651 & 0.531651 & 1.906871 & 0.673135 & 9.828354 \\
\hline $\mathrm{ZnO}$ & 0.000590 & 0.000590 & nd & nd & nd \\
\hline $\mathrm{ZrO}_{2}$ & 0.000496 & 0.000496 & nd & nd & 0.692665 \\
\hline PCB & 0.000002 & 0.000002 & nd & nd & nd \\
\hline
\end{tabular}


Table 5. KE Basin Canister and Fuel Sludge Composition (2 pages)

\begin{tabular}{|c|c|c|c|c|c|}
\hline \multirow{2}{*}{ Analyte } & \multicolumn{2}{|c|}{ Canister Sludge } & \multicolumn{3}{|c|}{ Fuel Washing Sludge } \\
\hline & Ful1 & Empty & Internal & Coating & Pieces \\
\hline Other & 0.010235 & 0.010235 & 0.017895 & 0.036809 & 0.056162 \\
\hline Total, g/cc: & 0.88411 & 0.88411 & 2.31948 & 0.96901 & 10.61847 \\
\hline Dry Density: & 0.884 & 0.884 & 2.312 & 0.969 & 10.611 \\
\hline Wet Density: & 1.62 & 1.62 & 3.00 & 1.50 & 11.02 \\
\hline \multicolumn{6}{|c|}{ Miscellaneous Characteristics of KE Basin Sludges } \\
\hline Volume, $\mathrm{m}^{3}:$ & 3.00 & 0.40 & 0.518 & 0.061 & 0.149 \\
\hline Volume, L: & 3,000 & 400 & 518 & 61 & 149 \\
\hline Wet Sludge, MT: & 4.86 & 0.65 & 1.55 & 0.09 & 1.64 \\
\hline Dry STudge, MT: & 2.65 & 0.35 & 1.20 & 0.06 & 1.58 \\
\hline Uranium, kg: & $1,408.97$ & 187.86 & 880.43 & 26.14 & $1,464.42$ \\
\hline \multicolumn{6}{|c|}{ Radiological Composition $(\mu \mathrm{C} i / g)$ of $K E$ Basin Sludges } \\
\hline$S r-90$ & $1,053.40$ & $1,053.40$ & $3,851.61$ & $1,767.75$ & $4,045.39$ \\
\hline$C s-137$ & 806.35 & 806.35 & $3,443.33$ & $1,410.00$ & $5,342.20$ \\
\hline $\mathrm{Pu}-239$ & 108.70 & 108.70 & 232.67 & 114.50 & 195.91 \\
\hline $\mathrm{Am}-241$ & 138.34 & 138.34 & 210.50 & 93.40 & 168.01 \\
\hline
\end{tabular}

Notes: Listed data comes from HNF-SD-SNF-TI-009 Rev 2. Data not given in the document is indicated by "nd". The specific activities needed to convert activity into mass for an isotope are listed below.

$\begin{array}{cc}\text { Sr-90: } & 139.03 \mathrm{ci} / \mathrm{g} \\ \mathrm{Cs}-137: & 86.55 \mathrm{ci} / \mathrm{g} \\ \mathrm{Pu}-239: & 0.06197 \mathrm{ci} / \mathrm{g} \\ \text { Am-241: } & 3.4314 \mathrm{ci} / \mathrm{g}\end{array}$


Table 6. KW Basin Canister and Fuel Sludge Composition (2 pages)

\begin{tabular}{|c|c|c|c|c|c|}
\hline \multirow{2}{*}{ Analyte } & \multicolumn{2}{|c|}{ Canister Sludge Cans } & \multicolumn{3}{|c|}{ Fuel Wash STudge } \\
\hline & Ful1 & Empty & Internal & Coating & Pieces \\
\hline \multicolumn{6}{|c|}{ Mass Densities $(\mathrm{g} / \mathrm{cc})$ of $\mathrm{KW}$ Basin Sludges } \\
\hline $\mathrm{Ag}_{2} \mathrm{O}$ & nd & nd & nd & nd & nd \\
\hline $\mathrm{Al}_{2} \mathrm{O}_{3}$ & 0.117661 & 0.117661 & 0.129080 & 0.544151 & nd \\
\hline Am & 0.000083 & 0.000083 & 0.000052 & 0.000001 & 0.000076 \\
\hline $\mathrm{B}_{2} \mathrm{O}_{3}$ & nd & nd & nd & nd & nd \\
\hline $\mathrm{BaO}$ & 0.000565 & 0.000565 & nd & nd & nd \\
\hline $\mathrm{BeO}$ & 0.000274 & 0.000274 & nd & nd & nd \\
\hline $\mathrm{BiO}$ & nd & nd & nd & nd & nd \\
\hline $\mathrm{CO}$ & 0.005844 & 0.005844 & nd & nd & nd \\
\hline $\mathrm{CaO}$ & nd & nd & nd & 0.004574 & nd \\
\hline $\mathrm{CdO}$ & nd & nd & nd & nd & nd \\
\hline $\mathrm{Cr}_{2} \mathrm{O}_{3}$ & 0.000935 & 0.000935 & nd & nd & nd \\
\hline CuO & nd & nd & nd & nd & nd \\
\hline $\mathrm{Fe}_{2} \mathrm{O}_{3}$ & 0.209042 & 0.209042 & 0.004031 & 0.306839 & nd \\
\hline $\mathrm{MgO}$ & nd & nd & nd & nd & nd \\
\hline $\mathrm{MnO}$ & 0.000733 & 0.000733 & nd & nd & nd \\
\hline $\mathrm{Na}_{2} \mathrm{O}$ & nd & nd & nd & nd & nd \\
\hline $\mathrm{NiO}$ & 0.000659 & 0.000659 & nd & nd & nd \\
\hline $\mathrm{PO}_{3}$ & nd & nd & nd & nd & nd \\
\hline $\mathrm{Pb} 0$ & nd & nd & nd & nd & nd \\
\hline $\mathrm{Pu}$ & 0.005648 & 0.005648 & 0.006865 & 0.000073 & 0.034805 \\
\hline $\mathrm{Se}$ & nd & nd & nd & nd & nd \\
\hline $\mathrm{SiO}_{2}$ & nd & nd & 0.194161 & 0.028835 & 0.000000 \\
\hline $\mathrm{Sm}_{2} \mathrm{O}_{3}$ & nd & nd & nd & nd & nd \\
\hline $\mathrm{Sr}$ & 0.000046 & 0.000046 & 0.000018 & nd & 0.000058 \\
\hline $\mathrm{Tl}_{2} \mathrm{O}_{3}$ & nd & nd & nd & nd & nd \\
\hline Uo & 1.497660 & 1.497660 & 1.888783 & 0.022194 & 9.828354 \\
\hline $\mathrm{ZnO}$ & 0.001537 & 0.001537 & nd & nd & nd \\
\hline $\mathrm{ZrO}_{2}$ & 0.001186 & 0.001186 & nd & nd & 0.692665 \\
\hline PCB & 0.000015 & 0.000015 & nd & nd & nd \\
\hline
\end{tabular}


Table 6. KW Basin Canister and Fuel Sludge Composition (2 pages)

\begin{tabular}{|c|c|c|c|c|c|}
\hline \multirow{2}{*}{ Analyte } & \multicolumn{2}{|c|}{ Canister Sludge Cans } & \multicolumn{3}{|c|}{ Fuel Wash Sludge } \\
\hline & Ful1 & Empty & Internal & Coating & Pieces \\
\hline Other & 0.055248 & 0.055248 & 0.017895 & 0.036809 & 0.056162 \\
\hline Total: & 1.89714 & 1.89714 & 2.24088 & 0.94348 & 10.61212 \\
\hline Dry Density: & 2.053 & 2.053 & 2.31 & 0.97 & 10.612 \\
\hline Wet Density: & 2.68 & 2.68 & 3.00 & 1.50 & 11.02 \\
\hline Unlisted: & 0.15586 & 0.15586 & 0.06912 & 0.02652 & -0.00012 \\
\hline \multicolumn{6}{|c|}{ Miscellaneous Characteristics of KW Basin Sludges } \\
\hline Volume, $\mathrm{m}^{3}:$ & 1.01 & 0.13 & 0.518 & 0.405 & 0.149 \\
\hline Volume, L: & 1,010 & 135 & 518 & 405 & 149 \\
\hline Wet Sludge, MT: & 2.71 & 0.36 & 1.55 & 0.61 & 1.64 \\
\hline Dry Sludge, MT: & 2.07 & 0.28 & 1.20 & 0.39 & 1.58 \\
\hline Uranium, kg: & $1,329.96$ & 177.33 & 880.43 & 26.14 & $1,464.42$ \\
\hline \multicolumn{6}{|c|}{ Radiological Composition $(\mu \mathrm{Ci} / \mathrm{g})$ of $\mathrm{KW}$ Basin Sludges } \\
\hline $5 r-90$ & $3,096.25$ & $3,096.25$ & $2,116.08$ & 92.90 & $5,065.27$ \\
\hline Cs-137 & $1,898.75$ & $1,898.75$ & $2,210.00$ & 57.70 & $6,505.54$ \\
\hline $\mathrm{Pu}-239$ & 175.03 & 175.03 & 184.00 & 4.62 & 203.12 \\
\hline$A m-241$ & 136.66 & 136.66 & 148.00 & 4.38 & 165.58 \\
\hline
\end{tabular}

Notes: Listed data comes from HNF-SD-SNF-T1-009 Rev 2. Data not given in the document is indicated by "nd". The specific activities needed to convert activity into mass for an isotope are listed below.

$\begin{array}{lc}\text { Sr-90: } & 139.03 \mathrm{Ci} / \mathrm{g} \\ \text { Cs-137: } & 86.55 \mathrm{Ci} / \mathrm{g} \\ \text { Pu-239: } & 0.06197 \mathrm{Ci} / \mathrm{g} \\ \text { Am-241: } & 3.4314 \mathrm{ci} / \mathrm{g}\end{array}$




\section{Concentration-Weighted Risk Guidelines}

The method used to calculate toxicological air concentrations in relation to the $\mathrm{DOE}-\mathrm{RL}$ acceptance guideline is summarized in the discussion below, taken from HNF-SD-SNF-TI-059.

For toxic chemicals the accumulated dose is not computed. Rather, the air concentration is determined and compared with guidelines. Health effects from exposure to contaminated air depend on the chemical, the air concentration, and the exposure time. For corrosive chemicals, the air concentration alone determines the amount of damage. Noncorrosive chemicals are carcinogens or have toxic effects based on the amount accumulated in the body. For noncorrosive chemicals the health effects depend on exposure time.

For accidents with release durations less than the transition times associated with each receptor distance, the puff model is appropriate for calculating air concentrations. The peak air concentration is calculated using the following equation:

$$
C_{\text {puff }}=(M)(X / Q)
$$

where

$$
\begin{aligned}
C_{\text {puff }}= & \text { peak concentration at a downwind receptor location, grams per } \\
& \text { cubic meter } \\
M= & \text { mass of the toxic chemical released, grams } \\
X / Q= & \text { puff release air transport factor, per cubic meter. }
\end{aligned}
$$

For accidents with release durations greater than the transition times, the plume model is appropriate for calculating air concentrations. The average air concentration during plume passage is calculated using the following equation:

$$
C_{\text {plume }}=(M)\left(X / Q^{\prime}\right) / T_{\text {ret }}
$$

where

$$
\begin{aligned}
C_{\text {plume }}= & \text { average plume concentration at a downwind receptor location, } \\
& \text { grams per cubic meter } \\
M= & \text { mass of the toxic chemical released, grams } \\
X / Q^{\prime}= & \text { continuous release air transport factor, seconds per cubic } \\
& \text { meter } \\
T_{\text {rel }}= & \text { release duration, seconds. }
\end{aligned}
$$


For short release durations, the air concentrations can become quite 1 arge for brief periods. To accommodate this effect in a conservative way, the concept of an averaging period has been developed. One calculates the average concentration during some minimum period and compares this concentration with the concentration guideline. The averaging time used in the present calculations is 15 minutes, based on the following guidance from WSRC-MS-92-206, Rev 2, Toxic Chemical Hazard Classification and Risk Acceptance Guidelines for Use in DOE Facilities (Craig et a1. 1995):

4.2 Exposure time: Concentrations for comparison with the guidelines must be calculated as the peak 15-minute average concentrations, which are then compared with the guideline concentration limits. This is applicable for all chemicals for which the toxic effect is immediate (i.e., concentrationdependent). If it is known that the toxic effects of a chemical are not concentration-dependent, but depend on the total quantity of chemical taken up by the body (i.e., dose-dependent), then the peak 1-hour concentration may be used. Concentration dependent chemicals are defined as fast-acting chemicals whose toxic effects are immediate, and correlate more closely to concentration than dose. Included in this category are sensory irritants and chemicals which are corrosive or vesicant in their action. Any chemical which has been assigned an OSHA PEL-STEL or PEL-C, or an ACGIH TLV-STEL or TLV-C value must be considered concentrationdependent. In contrast, the effects of dose-dependent chemicals are a function of both concentration and duration of exposure. However, a chemical may elicit concentration-dependent effects at high levels and dose-dependent effects at lower concentrations.

Since the exposure averaging time (15 minutes or 900 seconds) is greater than all the transition times computed in HNF-SD-SNF-TI-059, puff releases are eliminated from further consideration. Air concentrations from accidents with release durations less than 15 minutes are calculated using the plume equation with the release time set to 900 seconds. This is summarized in the modified equation below.

$$
C_{\text {ave }}=(M)\left(X / Q^{\prime}\right) / \max \left(T_{\text {rel }}, T_{\text {ave }}\right)
$$

where

$$
\begin{aligned}
C_{\text {ave }}= & \text { average concentration of a chemical at a downwind receptor } \\
& \text { location, grams per cubic meter } \\
M= & \text { mass of the toxic chemical released, grams } \\
X / Q^{\prime}= & \text { continuous release air transport factor, seconds per cubic } \\
& \text { meter } \\
T_{r e l}= & \text { release duration, seconds } \\
T_{\text {ave }}= & \text { exposure averaging period, } 900 \text { seconds. }
\end{aligned}
$$


When more than one chemical is released, a sum-of-fractions method is used to evaluate concentrations against the risk guidelines. The sum-offractions method was adapted from American Conference of Governmental Industrial Hygienists (ACGIH) and Occupational Safety and Health Administration (OSHA) methods for adding combined exposures to compounds with similar health effects:

$$
\text { SOF }=\sum_{K}\left(C_{K}\right) /\left(C G_{K}\right)
$$

where

$$
\begin{aligned}
\text { SOF }= & \text { sum-of-fractions for a mixture of chemicals in air } \\
C_{K}= & \text { calculated average air concentration for the Kth chemical, } \\
& \text { grams per cubic meter } \\
C G_{K}= & \text { concentration guide for the Kth chemical, grams of chemical } \\
& \text { per cubic meter of air }
\end{aligned}
$$

When the formula for average air concentration at the downwind receptor location is substituted into the SOF formula, the result is shown below. The sum over ratios of mass fraction divided by concentration guideline has been written as CWRG. The inverse of a CWRG is a composition-weighted concentration guideline for sludge, i.e., an effective concentration guideline for $K$ basins sludge.

$$
\begin{gathered}
\text { SOF }=\sum_{K}(M)\left(M F_{K}\right)\left(x / Q^{\prime}\right) / \max \left(T_{\text {rel }}, T_{\text {ave }}\right) /\left(C G_{K}\right) \\
\text { SOF }=(M)(C W R G)\left(x / Q^{\prime}\right) / \max \left(T_{\text {rel }}, T_{\text {ave }}\right) \\
\text { CWRG }=\sum_{K}\left(M F_{K}\right) /\left(C G_{K}\right)
\end{gathered}
$$

where

$$
\begin{aligned}
\text { SOF }= & \text { sum-of-fractions for a mixture of chemicals (eg., sludge) } \\
& \text { suspended in air } \\
M= & \text { total mass of sludge (a mixture of chemicals) released into } \\
& \text { the air as respirable particles, grams } \\
M F_{K}= & \text { mass fractions for a mixture of chemicals, i.e., mass of the } \\
& \text { Kth chemical per gram of total sludge } \\
X / Q^{\prime}= & \text { continuous release air transport factor, seconds per cubic } \\
& \text { meter } \\
T_{\text {rel }}= & \text { release duration, seconds } \\
T_{\text {ave }}= & \text { exposure averaging period, } 900 \text { seconds. }
\end{aligned}
$$



CWRG = composition-weighted risk guideline, cubic meters per gram of sludge
$C G_{K}=$ concentration guide for the Kth chemical, grams of chemical per cubic meter of air.

The normalized composition of sludge $\left(\mathrm{MF}_{\mathrm{K}}\right)$ is listed in Tables 7,8 , and 9. The values in these tables were computed from those shown in Tables 4, 5, and 6 by dividing the total concentration into the concentrations of each component. Note that the total density of the components is used rather than the wet or dry bulk density to calculate the mass fractions. In some cases the total of the numbers in a column is less than 1.00. This happens because the "Other" component is not shown in the tables.

Note that one more refinement will be included for long duration releases to ensure the comparison of toxicological and radiological risk can be considered bounding. In the event that the release duration is greater than the time characteristic of the risk evaluation guideline (1 hour or 8 hours), then the concentration guideline should be reduced. This approach is based on the observation that the total amount inhaled is related to the health effects on individuals downwind. Mathematically, one changes the definition of the concentration guideline to that shown below.

$$
\begin{aligned}
& \text { If } T_{\text {rel }}<T_{\text {guide }} \text {, then } C G_{K}^{\prime}=C G_{K} \\
& \text { If } T_{\text {rel }}>T_{\text {guide }} \text {, then } C G_{K}^{\prime}=\left(C G_{K}\right)\left(T_{\text {guide }}\right) /\left(T_{\text {rel }}\right) \\
& \text { or, } C G_{K}^{\prime}=\left(C G_{K}\right) \cdot \min \left[1,\left(T_{\text {guide }}\right) /\left(T_{\text {rel }}\right)\right]
\end{aligned}
$$

With this revised definition of concentration guides for long duration releases, it is necessary to revise the formula for sum-of-fractions. The formula below shows the results of the revision. Note that the main effect of the revision is to limit the release duration $\left(T_{\text {rel }}\right)$ to the time inherent in the risk evaluation guideline $\left(T_{\text {guide }}\right)$. For release durations less than $T_{\text {ave }}$, the formula uses the minimum averaging time. For release durations longer than $\mathrm{T}_{\text {ave }}$ but shorter than $\mathrm{T}_{\text {guide }}$, the formula uses the release duration. For release durations longer than $\left.\right|_{\text {guide, }}$ the formula uses the guideline time.

$$
\text { SOF }=(M)(C W R G)\left(X / Q^{\prime}\right) / \min \left[T_{\text {guide }}, \max \left(T_{\text {rel }}, T_{\text {ave }}\right)\right]
$$

This equation should be used when it is necessary to determine the toxicological consequences of accidental releases from $K$ basins. Sum-offractions that are less than one indicate that risk evaluation guidelines are met. Sum-of-fractions that are greater than one indicate that risk evaluation guidelines are exceeded and some type of control must be added to lower the probability of the accident. 
Table 7. Normalized KE Basin General Sludge ( $\mathrm{g} / \mathrm{g}$ sludge)

\begin{tabular}{|c|c|c|c|c|c|}
\hline Analyte & Wease1 Pit & $\begin{array}{c}\text { Main Basin } \\
\text { Floor }\end{array}$ & $\begin{array}{c}\text { Tech View } \\
\text { Pit }\end{array}$ & $\begin{array}{c}\text { North } \\
\text { Loadout Pit }\end{array}$ & Elevator Pit \\
\hline $\mathrm{Ag}_{2} \mathrm{O}$ & $1.975 \mathrm{E}-05$ & $1.980 \mathrm{E}-05$ & $1.975 \mathrm{E}-05$ & 0.000 & $1.975 \mathrm{E}-05$ \\
\hline $\mathrm{Al}_{2} \mathrm{O}_{3}$ & $7.307 \mathrm{E}-02$ & $1.170 E-01$ & $7.307 \quad E-02$ & $3.816 \quad E-02$ & $7.307 \mathrm{E}-02$ \\
\hline $\mathrm{Am}$ & $2.601 \mathrm{E}-05$ & $1.868 \mathrm{E}-04$ & $2.601 \mathrm{E}-05$ & $1.336 \mathrm{E}-05$ & $2.601 \mathrm{E}-05$ \\
\hline $\mathrm{B}_{2} \mathrm{O}_{3}$ & $4.717 \mathrm{E}-04$ & $8.570 \mathrm{E}-04$ & $4.717 \mathrm{E}-04$ & 0.000 & $4.717 \mathrm{E}-04$ \\
\hline $\mathrm{BaO}$ & $4.403 \mathrm{E}-04$ & $3.139 E-04$ & $4.403 \mathrm{E}-04$ & $1.759 \mathrm{E}-04$ & $4.403 E-04$ \\
\hline $\mathrm{BeO}$ & $5.228 \mathrm{E}-05$ & $1.471 \mathrm{E}-04$ & $5.228 \mathrm{E}-05$ & $4.329 \mathrm{E}-05$ & $5.228 \quad E-05$ \\
\hline $\mathrm{BiO}$ & 0.000 & 0.000 & 0.000 & 0.000 & 0.000 \\
\hline $\mathrm{CO}$ & $8.829 E-03$ & $1.705 \mathrm{E}-02$ & $8.829 \mathrm{E}-03$ & 0.000 & $8.829 E-03$ \\
\hline $\mathrm{CaO}$ & $1.855 \mathrm{E}-02$ & $8.731 E-03$ & $1.855 \mathrm{E}-02$ & $1.001 \mathrm{E}-02$ & $1.855 \mathrm{E}-02$ \\
\hline $\mathrm{CdO}$ & $5.809 \mathrm{E}-05$ & $1.697 \mathrm{E}-04$ & $5.809 E-05$ & $1.380 \mathrm{E}-04$ & 5.809 E-05 \\
\hline $\mathrm{Cr}_{2} \mathrm{O}_{3}$ & $1.549 \mathrm{E}-03$ & $8.570 \mathrm{E}-04$ & $1.549 \mathrm{E}-03$ & $3.301 \mathrm{E}-04$ & $1.549 \mathrm{E}-03$ \\
\hline $\mathrm{CuO}$ & $5.030 \mathrm{E}-04$ & $8.174 \mathrm{E}-04$ & $5.030 \mathrm{E}-04$ & $6.466 \mathrm{E}-04$ & $5.030 \mathrm{E}-04$ \\
\hline $\mathrm{Fe}_{2} \mathrm{O}_{3}$ & $4.682 \mathrm{E}-01$ & $3.640 \mathrm{E}-01$ & $4.682 \mathrm{E}-01$ & $1.022 \mathrm{E}-01$ & $4.682 \quad E-01$ \\
\hline $\mathrm{MgO}$ & $3.326 \mathrm{E}-03$ & $2.975 \mathrm{E}-03$ & $3.326 \mathrm{E}-03$ & $1.683 \mathrm{E}-03$ & $3.326 \mathrm{E}-03$ \\
\hline MnO & $6.773 \mathrm{E}-04$ & $6.929 E-04$ & $6.773 \mathrm{E}-04$ & $8.739 \mathrm{E}-04$ & $6.773 \quad \mathrm{E}-04$ \\
\hline $\mathrm{Na}_{2} \mathrm{O}$ & $1.122 \mathrm{E}-03$ & $4.336 \mathrm{E}-03$ & $1.122 \mathrm{E}-03$ & 0.000 & $1.122 E-03$ \\
\hline $\mathrm{NiO}$ & 0.000 & 0.000 & 0.000 & 0.000 & 0.000 \\
\hline $\mathrm{PO}_{3}$ & 0.000 & 0.000 & 0.000 & 0.000 & 0.000 \\
\hline $\mathrm{PbO}$ & $5.518 \mathrm{E}-04$ & $5.176 \mathrm{E}-04$ & $5.518 \mathrm{E}-04$ & $2.841 \mathrm{E}-04$ & $5.518 \quad E-04$ \\
\hline $\mathrm{Pu}$ & $8.829 \mathrm{E}-05$ & $2.885 E-04$ & $8.829 \mathrm{E}-05$ & $1.623 \mathrm{E}-04$ & $8.829 \mathrm{E}-05$ \\
\hline Se & $2.010 \mathrm{E}-04$ & $1.782 \mathrm{E}-04$ & $2.010 \mathrm{E}-04$ & 0.000 & $2.010 \mathrm{E}-04$ \\
\hline $\mathrm{SiO}_{2}$ & $2.734 \mathrm{E}-01$ & $2.091 \mathrm{E}-01$ & $2.734 \mathrm{E}-01$ & $8.037 \mathrm{E}-01$ & $2.734 \mathrm{E}-01$ \\
\hline $\mathrm{Sm}_{2} \mathrm{O}_{3}$ & $2.335 \mathrm{E}-04$ & $2.065 E-04$ & $2.335 \mathrm{E}-04$ & $1.136 \mathrm{E}-04$ & $2.335 \mathrm{E}-04$ \\
\hline $\mathrm{Sr}$ & $1.756 \mathrm{E}-05$ & $4.957 \quad E-05$ & $1.756 \mathrm{E}-05$ & 0.000 & $1.756 \mathrm{E}-05$ \\
\hline $\mathrm{Tl}_{2} \mathrm{O}_{3}$ & $3.996 \mathrm{E}-04$ & 3.846 E-04 & $3.996 \mathrm{E}-04$ & $2.841 E-04$ & $3.996 \mathrm{E}-04$ \\
\hline UO & $7.368 \quad E-02$ & $1.088 E-01$ & $7.368 \mathrm{E}-02$ & $4.119 \mathrm{E}-02$ & $7.368 \mathrm{E}-02$ \\
\hline $\mathrm{ZnO}$ & $1.357 \mathrm{E}-03$ & $1.233 E-03$ & $1.357 \mathrm{E}-03$ & 0.000 & $1.357 \quad E-03$ \\
\hline $\mathrm{ZrO}_{2}$ & $7.818 E-04$ & $6.335 \mathrm{E}-04$ & $7.818 \mathrm{E}-04$ & 0.000 & $7.818 \mathrm{E}-04$ \\
\hline $\mathrm{PCB}$ & $2.614 \mathrm{E}-04$ & $2.347 \quad E-04$ & $2.614 \mathrm{E}-04$ & 0.000 & $2.614 \mathrm{E}-04$ \\
\hline Tota1: & 0.9278811 & 0.8397755 & 0.9278811 & 1 & 0.9278811 \\
\hline
\end{tabular}

The above mass ratios are computed from the mass concentrations and total shown in Table 4. The total mass concentration has been divided into the concentration of each component. The totals are not 1.00 because the component "Other" has been omitted. 
Table 8. Normalized KE Basin Canister and Fuel Sludge (g/g sludge)

\begin{tabular}{|c|c|c|c|c|c|}
\hline \multirow{2}{*}{ Analyte } & \multicolumn{2}{|c|}{ Canister Sludge } & \multicolumn{3}{|c|}{ Fuel Washing Sludge } \\
\hline & Ful1 & Empty & Internal & Coating & Pieces \\
\hline $\mathrm{Ag} 20$ & $1.063 \mathrm{E}-04$ & $1.063 \mathrm{E}-04$ & 0.000 & 0.000 & 0.000 \\
\hline A1203 & $1.923 \mathrm{E}-01$ & $1.923 \mathrm{E}-01$ & $1.095 \mathrm{E}-02$ & $2.206 \mathrm{E}-01$ & 0.000 \\
\hline $\mathrm{Am}$ & $1.209 \mathrm{E}-04$ & $1.209 \mathrm{E}-04$ & $3.167 E-05$ & $1.660 \mathrm{E}-06$ & $7.290 \mathrm{E}-06$ \\
\hline B203 & $1.062 \mathrm{E}-03$ & $1.062 \mathrm{E}-03$ & 0.000 & 0.000 & 0.000 \\
\hline $\mathrm{BaO}$ & 1.832 E-04 & $1.832 \mathrm{E}-04$ & 0.000 & 0.000 & 0.000 \\
\hline $\mathrm{BeO}$ & $2.240 \mathrm{E}-04$ & $2.240 \mathrm{E}-04$ & 0.000 & 0.000 & 0.000 \\
\hline $\mathrm{BiO}$ & $4.671 \mathrm{E}-04$ & $4.671 \mathrm{E}-04$ & 0.000 & 0.000 & 0.000 \\
\hline $\mathrm{CO}$ & $1.120 E-02$ & $1.120 \mathrm{E}-02$ & $3.277 E-03$ & 0.000 & $7.157 \mathrm{E}-04$ \\
\hline $\mathrm{CaO}$ & $1.837 \mathrm{E}-03$ & $1.837 \mathrm{E}-03$ & 0.000 & $1.536 \mathrm{E}-02$ & 0.000 \\
\hline $\mathrm{CdO}$ & $9.501 \mathrm{E}-05$ & $9.501 \mathrm{E}-05$ & 0.000 & 0.000 & 0.000 \\
\hline $\mathrm{Cr} 203$ & $6.526 \mathrm{E}-04$ & $6.526 \mathrm{E}-04$ & 0.000 & 0.000 & 0.000 \\
\hline $\mathrm{CuO}$ & $5.441 \mathrm{E}-04$ & $5.441 \mathrm{E}-04$ & 0.000 & 0.000 & 0.000 \\
\hline $\mathrm{Fe} 203$ & $1.237 \quad E-01$ & $1.237 \mathrm{E}-01$ & $1.875 \mathrm{E}-03$ & $2.954 \mathrm{E}-02$ & 0.000 \\
\hline MgO & $2.658 \mathrm{E}-03$ & $2.658 \mathrm{E}-03$ & 0.000 & 0.000 & 0.000 \\
\hline $\mathrm{MnO}$ & $5.158 \mathrm{E}-04$ & $5.158 \mathrm{E}-04$ & 0.000 & 0.000 & 0.000 \\
\hline $\mathrm{Na} 20$ & $9.117 \quad E-04$ & $9.117 \mathrm{E}-04$ & 0.000 & 0.000 & 0.000 \\
\hline $\mathrm{NiO}$ & $2.862 \quad E-04$ & $2.862 \mathrm{E}-04$ & 0.000 & 0.000 & 0.000 \\
\hline $\mathrm{P} 03$ & $2.281 E-03$ & $2.281 E-03$ & 0.000 & 0.000 & 0.000 \\
\hline $\mathrm{PbO}$ & 4.671 E-04 & 4.671 E-04 & 0.000 & 0.000 & 0.000 \\
\hline $\mathrm{Pu}$ & $1.737 \mathrm{E}-03$ & $1.737 E-03$ & $3.743 \mathrm{E}-03$ & $1.851 \quad E-03$ & $3.161 \mathrm{E}-03$ \\
\hline $\mathrm{Se}$ & 0.000 & 0.000 & 0.000 & 0.000 & 0.000 \\
\hline $\mathrm{SiO2}$ & $4.441 \mathrm{E}-02$ & $4.441 E-02$ & $1.503 \mathrm{E}-01$ & 0.000 & 0.000 \\
\hline Sm203 & 0.000 & 0.000 & 0.000 & 0.000 & 0.000 \\
\hline $\mathrm{Sr}$ & $2.273 E-05$ & $2.273 \mathrm{E}-05$ & $1.430 \mathrm{E}-05$ & $7.756 \mathrm{E}-07$ & $4.332 \mathrm{E}-06$ \\
\hline $\mathrm{T1203}$ & 0.000 & 0.000 & 0.000 & 0.000 & 0.000 \\
\hline UO & $6.013 \mathrm{E}-01$ & $6.013 \mathrm{E}-01$ & $8.221 \mathrm{E}-01$ & $6.947 \mathrm{E}-01$ & $9.256 \mathrm{E}-01$ \\
\hline $\mathrm{ZnO}$ & $6.673 \mathrm{E}-04$ & $6.673 \quad E-04$ & 0.000 & 0.000 & 0.000 \\
\hline $\operatorname{Zr02}$ & 5.610 E-04 & $5.610 \mathrm{E}-04$ & 0.000 & 0.000 & $6.523 \mathrm{E}-02$ \\
\hline PCB & $2.036 \mathrm{E}-06$ & $2.036 E-06$ & 0.000 & 0.000 & 0.000 \\
\hline Tota 1: & 0.988423 & 0.988423 & 0.992285 & 0.962014 & 0.994711 \\
\hline
\end{tabular}

The above mass ratios are computed from the mass concentrations and total shown in Table 5. The total mass concentration has been divided into the concentration of each component. The totals are not 1.00 because the component "other" has been omitted. 
Table 9. Normalized KW Basin Canister and Fuel Sludge (g/g sludge)

\begin{tabular}{|c|c|c|c|c|c|}
\hline \multirow{2}{*}{ Analyte } & \multicolumn{2}{|c|}{ Canister Sludge } & \multicolumn{3}{|c|}{ Fuel Washing Sludge } \\
\hline & Ful1 & Empty & Internal & Coating & Pieces \\
\hline $\mathrm{Ag} 20$ & 0.000 & 0.000 & 0.000 & 0.000 & 0.000 \\
\hline A1203 & $6.202 \mathrm{E}-02$ & $6.202 \mathrm{E}-02$ & $5.760 \mathrm{E}-02$ & $5.768 \mathrm{E}-01$ & 0.000 \\
\hline $\mathrm{Am}$ & $4.353 \mathrm{E}-05$ & $4.353 \mathrm{E}-05$ & $2.303 E-05$ & $5.315 \quad E-07$ & $7.190 \mathrm{E}-06$ \\
\hline $\mathrm{B} 203$ & 0.000 & 0.000 & 0.000 & 0.000 & 0.000 \\
\hline $\mathrm{BaO}$ & $2.978 \mathrm{E}-04$ & $2.978 \mathrm{E}-04$ & 0.000 & 0.000 & 0.000 \\
\hline $\mathrm{BeO}$ & 1.444 E-04 & $1.444 \mathrm{E}-04$ & 0.000 & 0.000 & 0.000 \\
\hline $\mathrm{BiO}$ & 0.000 & 0.000 & 0.000 & 0.000 & 0.000 \\
\hline $\mathrm{CO}$ & $3.080 E-03$ & $3.080 E-03$ & 0.000 & 0.000 & 0.000 \\
\hline $\mathrm{CaO}$ & 0.000 & 0.000 & 0.000 & $4.848 E-03$ & 0.000 \\
\hline $\mathrm{CdO}$ & 0.000 & 0.000 & 0.000 & 0.000 & 0.000 \\
\hline $\mathrm{Cr} 203$ & $4.928 E-04$ & $4.928 \mathrm{E}-04$ & 0.000 & 0.000 & 0.000 \\
\hline $\mathrm{CuO}$ & 0.000 & 0.000 & 0.000 & 0.000 & 0.000 \\
\hline $\mathrm{Fe} 203$ & $1.102 \mathrm{E}-01$ & $1.102 \mathrm{E}-01$ & $1.799 \mathrm{E}-03$ & $3.252 \mathrm{E}-01$ & 0.000 \\
\hline $\mathrm{MgO}$ & 0.000 & 0.000 & 0.000 & 0.000 & 0.000 \\
\hline $\mathrm{MnO}$ & $3.864 E-04$ & $3.864 E-04$ & 0.000 & 0.000 & 0.000 \\
\hline $\mathrm{Na} 20$ & 0.000 & 0.000 & 0.000 & 0.000 & 0.000 \\
\hline $\mathrm{NiO}$ & $3.474 \quad E-04$ & $3.474 \mathrm{E}-04$ & 0.000 & 0.000 & 0.000 \\
\hline P03 & 0.000 & 0.000 & 0.000 & 0.000 & 0.000 \\
\hline $\mathrm{PbO}$ & 0.000 & 0.000 & 0.000 & 0.000 & 0.000 \\
\hline $\mathrm{Pu}$ & $2.977 \mathrm{E}-03$ & $2.977 \mathrm{E}-03$ & $3.064 \mathrm{E}-03$ & $7.737 \mathrm{E}-05$ & $3.280 E-03$ \\
\hline $\mathrm{Se}$ & 0.000 & 0.000 & 0.000 & 0.000 & 0.000 \\
\hline $\mathrm{SiO}$ & 0.000 & 0.000 & $8.664 \mathrm{E}-02$ & $3.056 \mathrm{E}-02$ & 0.000 \\
\hline $\mathrm{Sm} 203$ & 0.000 & 0.000 & 0.000 & 0.000 & 0.000 \\
\hline $\mathrm{Sr}$ & $2.434 E-05$ & $2.434 \mathrm{E}-05$ & $8.127 \mathrm{E}-06$ & $2.782 \mathrm{E}-07$ & $5.428 E-06$ \\
\hline $\mathrm{T} 1203$ & 0.000 & 0.000 & 0.000 & 0.000 & 0.000 \\
\hline UO & 7.894 E-01 & $7.894 \mathrm{E}-01$ & $8.429 \mathrm{E}-01$ & $2.352 \mathrm{E}-02$ & $9.261 \quad E-01$ \\
\hline $\mathrm{ZnO}$ & $8.102 \mathrm{E}-04$ & 8.102 E-04 & 0.000 & 0.000 & 0.000 \\
\hline Zr02 & $6.252 \mathrm{E}-04$ & $6.252 \mathrm{E}-04$ & 0.000 & 0.000 & $6.527 \mathrm{E}-02$ \\
\hline PCB & 7.907 E-06 & $7.907 \quad E-06$ & 0.000 & 0.000 & 0.000 \\
\hline Total: & 0.970878 & 0.970878 & 0.992014 & 0.960986 & 0.994708 \\
\hline
\end{tabular}

The above mass ratios are computed from the mass concentrations and total shown in Table 6. The total mass concentration has been divided into the concentration of each component. The totals are not 1.00 because the component "other" has been omitted. 
Note that the released material is assumed to have the same composition as sludge. If an accident results in additional chemicals besides the materials in sludge, then a new CWRG must be generated.

The toxicological calculations addressed in this report use the above equation. The calculations for toxic chemical releases should be carried out using the steps shown below.

1. Determine the accident frequency range for the event.

2. Determine the quantity of material released into the air as respirable particles. It is also important to estimate the time required to release this material. If the duration exceeds 15 minutes, then the 15-minute period during the release that contains the greatest amount released must be used in the calculation of the Sum-of-fractions.

3. Determine the SOF by muttiplying the mass released by the air transport factor and the CWRG, and dividing by the appropriate time interva1. If the SOF is greater than 1.0 , then controls must be established to lower the probability of the accident or the mass released.

Using the mass fractions shown in Tables 7, 8, and 9, and the concentration guidelines shown in Table 3 , the CWRGs for $K$ basins sludge are calculated and 1isted in Table 10. The contribution of the TRU to the CWRG is included by assuming that americium and plutonium are chemically similar to uranium in the body. By this assumption, the concentration guides for uranium are also used for americium and plutonium. The values for CWRG are given in more detail in Appendix B. Appendix B 1ists the contribution of each chemical to the total CWRG. In Appendix B the effective concentration limit is also shown. Last in the tables is the percent contribution of each compound to the total. From the percentages, it is evident that silicon oxide (as finely divided particulate, assumed respirable, and not agglomerated) is the main contributor to the toxicity of the general basin sludge.

\section{Comparison of Toxicological and Radiological}

Because any environmental release of sludge could have toxicological and radiological effects, both should be computed for comparison with consequence guidelines. A comparison will be presented in this section by using a ratio of radiological and toxicological ratios. The radiological (or toxicological) ratio shows the importance of a given release by comparing the resulting dose (or air concentration) with the risk evaluation guidelines. The ratio of these radiological and toxicological ratios simplifies the comparison so that a broader variety of accident conditions can be evaluated. 
Table 10. CWRG Values for KE Basin Sludge $\left(\mathrm{m}^{3} / \mathrm{g}\right)$

\begin{tabular}{|c|c|c|c|c|}
\hline & PEL-TWA & ERPG-1 & $E R P G-2$ & ERPG-3 \\
\hline \multicolumn{5}{|c|}{ KE Basin General Sludge } \\
\hline Weasel Pit & 4,590 & 1,170 & 754 & 23.1 \\
\hline Main Basin Floor & 4,690 & 1,020 & 680 & 26.3 \\
\hline Tech View Pit & 4,590 & 1,170 & 754 & 23.1 \\
\hline North Loadout Pit & 8,940 & 2,770 & 1,690 & 38.8 \\
\hline Elevator Pit & 4,590 & 1,170 & 754 & 23.1 \\
\hline \multicolumn{5}{|c|}{ KE Basin Canister and Fuel Wash Sludge } \\
\hline Canister Sludge -- Full & 12,701 & 1,210 & 1,120 & 72.3 \\
\hline Canister Sludge -- Empty & 12,701 & 1,210 & 1,120 & 72.3 \\
\hline Fuel Washing Sludge -- Internal & 18,022 & 1,880 & 1,680 & 89.0 \\
\hline Fuel Washing Sludge -- Coating & 13,958 & 1,180 & 1,180 & 79.1 \\
\hline Fuel Washing Sludge -- Pieces & 18,588 & 1,550 & 1,550 & 94.2 \\
\hline \multicolumn{5}{|c|}{ KW Basin Canister and Fuel Wash Sludge } \\
\hline Canister Sludge -- Full & 15,950 & 1,350 & 1,340 & 83.3 \\
\hline Canister Sludge -- Empty & 15,950 & 1,350 & 1,340 & 83.3 \\
\hline Fuel Washing Sludge -- Internal & 17,790 & 1,700 & 1,590 & 90.4 \\
\hline Fuel Washing Sludge -- Coating & 869 & 202 & 152 & 27.0 \\
\hline Fuel Washing Sludge -- Pieces & 18,600 & 1,560 & 1,550 & 94.2 \\
\hline
\end{tabular}

Note: Contributions from americium and plutonium are included by assuming the concentration guide for these elements is the same as that for uranium. Details are provided in Appendix B.

The formulas used to calculate the radiological and toxicological significance of airborne releases from $\mathrm{K}$ basins are shown below. For the purposes of comparison, the radiological consequence formula has been written as the dose equivalent divided by the radiological risk evaluation guideline. Both radiological and toxicological consequences are thereby reduced to unitless, risk-based ratios. The utility of risk-based ratios is that an accident with a ratio greater than 1.0 requires additional controls to lessen either the severity or probability of the accident. 


$$
\begin{gathered}
\text { Radiological ratio }=(M)\left(X / Q^{\prime}\right)(B R)(U D) /(R R G) \\
\text { Toxicological ratio }=(M)\left(X / Q^{\prime}\right)(C W R G) / \min \left[T_{\text {guide }}, \max \left(T_{\text {rel }}, T_{\text {ave }}\right)\right]
\end{gathered}
$$

where

$$
\begin{aligned}
M= & \text { mass of } K \text { basin sludge released into the air as respirable } \\
\text { particles, grams } & \\
X / Q^{\prime}= & \text { air transport factor, } \mathrm{s} / \mathrm{m}^{3} \text { (HNF-SD-SNF-TI-059) } \\
B R= & \text { average inhalation rate during the release, } \mathrm{m}^{3} / \mathrm{s} \\
U D= & \text { committed effective dose equivalent per gram inhaled, } \\
& 438,000 \text { rem } / g \text { (HNF-SD-SNF-TI-059) } \\
\text { RRG = } & \text { radiological risk evaluation guideline, rem (Table } 1 \text { ) } \\
\text { CWRG = } & \text { composition-weighted risk guidelines for sludge, } \mathrm{m}^{3} \text { per gram } \\
& \text { of sludge (Table } 10 \text { ) } \\
T_{\text {guide }}= & \text { time period characteristic of the toxicological risk } \\
& \text { guideline, seconds } \\
T_{\text {rel }}= & \text { release duration, seconds } \\
T_{\text {ave }}= & \text { exposure averaging period, } 900 \text { seconds. }
\end{aligned}
$$

Note that the same air transport factors are always used in both the radiological and toxicological calculations. When the ratio of radiological to toxicological is computed, the quantity released (M) and the air transport factors $\left(x / Q^{\prime}\right)$ cancel out. The resulting simplified ratio is shown below.

$$
W=\frac{\text { Radiological ratio }}{\text { Toxicological ratio }}=\frac{(B R)(U D) \min \left(T_{\text {guide }}, \max \left(T_{\text {rel }}, T_{\text {ave }}\right)\right)}{(R R G)(C W R G)}
$$

To minimize this ratio, the shortest time possible should be selected for the release duration. This shortest time is the exposure averaging time, 15 minutes (900 seconds). The numerator is then $\left.131,000 \mathrm{rem} \cdot \mathrm{m}^{3}\right) / \mathrm{g}$. Values for the denominator come from Tables 1 and 10, and depends on the location of the receptor (onsite or offsite) and the accident probability. Values for the above ratios of radiological to toxicological consequences were computed for each case. Results are shown in Table 11. The radiological ratios are greater than the toxicological ratios for any mass released and any release duration, i.e., $W$ is always greater than 1.0 for $K$ basins sludge. 
Table 11. "W" Ratios for K Basins Sludge

\begin{tabular}{|c|c|c|c|}
\hline & Anticipated & Unlikely & $\begin{array}{l}\text { Extremely } \\
\text { Unlikely }\end{array}$ \\
\hline \multicolumn{4}{|c|}{ KE Basin General Sludge } \\
\hline \multicolumn{4}{|l|}{ Wease] Pjt } \\
\hline Onsite: & 112 & 17 & 227 \\
\hline Offsite: & 57 & 22 & 35 \\
\hline \multicolumn{4}{|c|}{ Main Basin Floor } \\
\hline Onsite: & 129 & 19 & 200 \\
\hline Offsite: & 56 & 26 & 39 \\
\hline \multicolumn{4}{|c|}{ Tech View Pit } \\
\hline Onsite: & 112 & 17 & 227 \\
\hline Offsite: & 57 & 22 & 35 \\
\hline \multicolumn{4}{|c|}{ North Loadout Pit } \\
\hline Onsite: & 47 & 7.8 & 135 \\
\hline offsite: & 29 & 9.5 & 16 \\
\hline \multicolumn{4}{|l|}{ Elevator Pit } \\
\hline Onsite: & 112 & 17 & 227 \\
\hline offsite: & 57 & 22 & 35 \\
\hline \multicolumn{4}{|c|}{ KE Basin Canister and Fuel Wash siudge } \\
\hline \multicolumn{4}{|c|}{ Canister Sludge -- Full } \\
\hline Onsite: & 109 & 12 & 73 \\
\hline Offsite: & 21 & 22 & 23 \\
\hline \multicolumn{4}{|c|}{ Canister Sludge -- Empty } \\
\hline Onsite: & 109 & 12 & 73 \\
\hline offsite: & 21 & 22 & 23 \\
\hline \multicolumn{4}{|c|}{ Fuel Washing Sludge -- Internal } \\
\hline Onsite: & 70 & 7.8 & 59 \\
\hline Offsite: & 15 & 14 & 16 \\
\hline \multicolumn{4}{|c|}{ Fuel Washing Sludge -- Coating } \\
\hline Onsite: & 111 & 11 & 66 \\
\hline Offsite: & 19 & 22 & 22 \\
\hline
\end{tabular}


Table 11. "W" Ratios for K Basins Sludge

\begin{tabular}{|c|c|c|c|}
\hline & Anticipated & Unlikely & $\begin{array}{l}\text { Extremely } \\
\text { Unlikely }\end{array}$ \\
\hline Onsite: & 84 & 8.5 & 56 \\
\hline offsite: & 14 & 17 & 17 \\
\hline \multicolumn{4}{|c|}{ KW Basin Canister and Fuel Wash Sludge } \\
\hline \multicolumn{4}{|c|}{ Canister Sludge -- Full } \\
\hline Onsite: & 97 & 10 & 63 \\
\hline offsite: & 16 & 19 & 20 \\
\hline \multicolumn{4}{|c|}{ Canister Sludge -- Empty } \\
\hline Onsite: & 97 & 10 & 63 \\
\hline offsite: & 16 & 19 & 20 \\
\hline \multicolumn{4}{|c|}{ Fuel Washing Sludge -- Internal } \\
\hline Onsite: & 77 & 8.3 & 58 \\
\hline Offsite: & 15 & 15 & 17 \\
\hline \multicolumn{4}{|c|}{ Fuel Washing Sludge -- Coating } \\
\hline Onsite: & 649 & 86 & 195 \\
\hline Offsite: & 302 & 130 & 172 \\
\hline \multicolumn{4}{|c|}{ Fuel Washing Sludge -- Pieces } \\
\hline Onsite: & 84 & 8.5 & 56 \\
\hline offsite: & 14 & 17 & 17 \\
\hline
\end{tabular}

The quantity "W" is the radiological risk ratio divided by the toxicological risk ratio.

The assumed release duration is at most 15 minutes. Larger release durations increase the ratios shown above due to smaller toxicological consequences.

The preferential release of specific constituents in the sludge rather than the complete composition could affect the above ratios by changing the CWRG values. Apart from this caveat, it can be stated that for all accidents involving sludge, the radiological risk guidelines are more limiting than the toxicological guidelines. In other words, if the radiological risk is brought within radiological guidelines, the toxicological risk is below toxicological guidelines with margin. 


\section{REFERENCES}

AIHA, 1991, Emergency Response Planning Guidelines, American Industrial Hygiene Association, Akron, Ohio.

Craig, D. K., 1995, Toxic Chemical Hazard Classification and Risk Acceptance Guidelines for Use in DOE Facilities, WSRC-MS-92-206, Rev. 2, Westinghouse Savannah River Company, Aiken, South Carolina.

Craig, D. K., 1997, ERPGs and TEELs for Chemicals of Concern at SRS: Rev. 12 (July 9, 1997), PEC-CAT-97-0044A

HNF-SD-SNF-TI-009, 1998, 105-K Basin Material Design Basis Feed Description for Spent Nuclear Fuel Project Facilities, Volume 2, SLUDGE, Rev 2, Fluor Daniel Hanford, Incorporated, Richland, Washington.

HNF-SD-SNF-TI-059, 1999, A Discussion on the Methodology for Calculating Radiological and Toxicological Consequences for the Spent Nuclear Fuel Project at the Hanford Site, Rev 2, Fluor Daniel Hanford, Incorporated, Richl and, Washington.

Sellers, E. D., 1997, Risk Evaluation Guidelines (REGs) to Ensure Inherently Safer Designs (Letter 97-SFD-034 to H. J. Hatch, Fluor Daniel Hanford, Incorporated, May 23), U.S. Department of Energy, Richland Operations office, Richland, Washington. 
SNF-5066 Rev 0

Appendix A. Peer Reviewer Checklist 


\section{PEER REVIEW CHECKLIST}

Document Reviewed: SNF-5066 Revision 0, Comparison of Toxicological and Radiological Aspects of K-Basins Sludge

Scope of Review: whole thing

Yes No N/A

HA [ ] [ ] Previous reviews complete and cover analysis, up to scope of this review, with no gaps.

[X] [ ] [ ] Problem completely defined.

[] [ ] [X] Accident scenarios developed in a clear and logical manner.

$[X] \quad[] \quad[]$ Necessary assumptions explicitly stated and supported.

[]$\quad[] \quad[X]$ Computer codes and data files documented.

[X] [ ] [ ] Data used in calculations explicitly stated in document.

[ ] [ ] [ OOData checked for consistency with original source information as applicable.

[X] [ ] [ ] Mathematical derivations checked including dimensional consistency of results.

[X] [ ] [ ] Models appropriate and used within range of validity or use outside range of established validity justified.

[X] [ ] [ ] Hand calculations checked for errors. Spreadsheet results should be treated exactly the same as hand calculations.

[ ] [ ] [X] Software input correct and consistent with document reviewed.

[][]$[X]$ Software output consistent with input and with results reported in document reviewed.

[X] [ ] [ ] Limits/criteria/guidelines applied to analysis results are appropriate and referenced. Limits/criteria/guidelines checked against references.

[ ] [ ] $\$ Safety margins consistent with good engineering practices.

$[x][][]$ Conclusions consistent with analytical results and applicable limits.

[X] [ ] [ ] Results and conclusions address all points required in the problem statement.

[ ] [ ] [X] Format consistent with appropriate NRC Regulatory Guide or other standards

[ ] [ ] [X] Review calculations, comments, and/or notes are attached.

LX] [ ] Document approved.

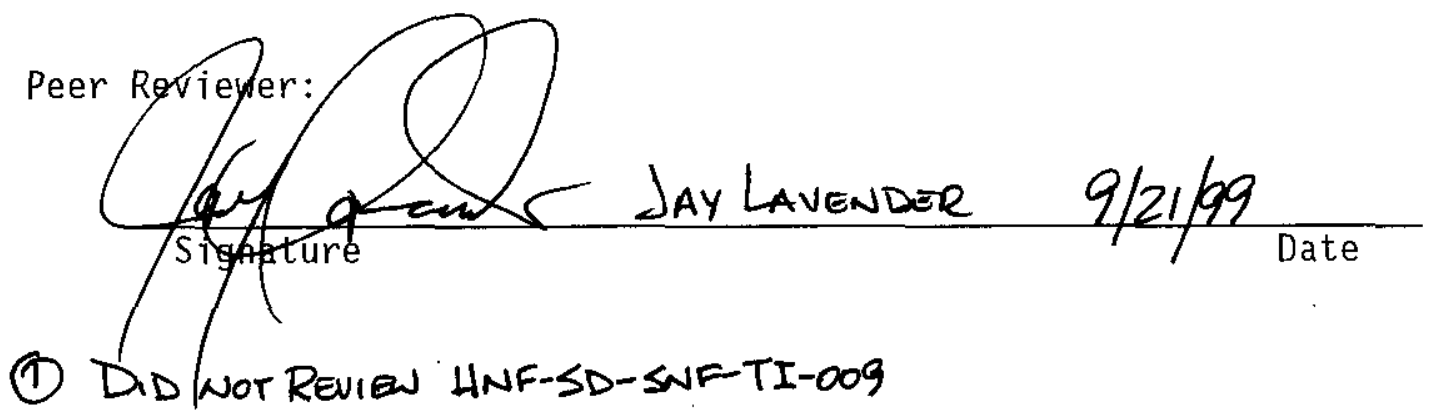


SNF-5066 Rev 0

Appendix B: Tables Showing Calculation of CWRG Numbers 
Table B-1. CWRG for the PEL-TWA Guideline -- KE Basin General Sludge

\begin{tabular}{|c|c|c|c|c|c|}
\hline Analyte & Wease I Pit & $\begin{array}{c}\text { Main Basin } \\
\text { Floor }\end{array}$ & $\begin{array}{c}\text { Tech View } \\
\text { Pit }\end{array}$ & $\begin{array}{l}\text { North } \\
\text { Loadout Pit }\end{array}$ & Elevator Pit \\
\hline \multicolumn{6}{|c|}{ Mass Fractions Divided by the PEL-TWA Guidel ine $\left(\mathrm{m}^{3} / \mathrm{g}\right)$} \\
\hline $\mathrm{Ag}_{2} \mathrm{O}$ & 1.975 & 1.980 & 1.975 & NA & 1.975 \\
\hline $\mathrm{Al}_{2} \mathrm{O}_{3}$ & 7.307 & 11.70 & 7.307 & 3.816 & 7.307 \\
\hline $\mathrm{Am}$ & 0.520 & 3.736 & 0.520 & 0.267 & 0.520 \\
\hline $\mathrm{B}_{2} \mathrm{O}_{3}$ & 0.047 & 0.086 & 0.047 & NA & 0.047 \\
\hline $\mathrm{BaO}$ & 0.881 & 0.628 & 0.881 & 0.352 & 0.881 \\
\hline $\mathrm{BeO}$ & 26.14 & 73.54 & 26.14 & 21.64 & 26.14 \\
\hline $\mathrm{BiO}$ & NA & NA & NA & NA & NA \\
\hline $\mathrm{CO}$ & 0.221 & 0.427 & 0.221 & $\mathrm{NA}$ & 0.221 \\
\hline $\mathrm{CaO}$ & 3.710 & 1.746 & 3.710 & 2.002 & 3.710 \\
\hline $\mathrm{CdO}$ & 11.62 & 33.94 & 11.62 & 27.60 & 11.62 \\
\hline $\mathrm{Cr}_{2} \mathrm{O}_{3}$ & 3.097 & 1.714 & 3.097 & 0.660 & 3.097 \\
\hline $\mathrm{CuO}$ & 0.503 & 0.817 & 0.503 & 0.647 & 0.503 \\
\hline $\mathrm{Fe}_{2} \mathrm{O}_{3}$ & 46.82 & 36.40 & 46.82 & 10.22 & 46.82 \\
\hline $\mathrm{MgO}$ & 0.333 & 0.298 & 0.333 & 0.168 & 0.333 \\
\hline MnO & 3.386 & 3.465 & 3.386 & 4.370 & 3.386 \\
\hline $\mathrm{Na}_{2} \mathrm{O}$ & 0.112 & 0.434 & 0.112 & NA & 0.112 \\
\hline $\mathrm{NiO}$ & NA & NA & NA & NA & NA \\
\hline $\mathrm{PO}_{3}$ & NA & NA & NA & NA & NA \\
\hline $\mathrm{PbO}$ & 11.04 & 10.35 & 11.04 & 5.682 & 11.04 \\
\hline $\mathrm{Pu}$ & 1.766 & 5.770 & 1.766 & 3.247 & 1.766 \\
\hline $\mathrm{Se}$ & 1.005 & 0.891 & 1.005 & NA & 1.005 \\
\hline $\mathrm{SiO}_{2}$ & 2,734 & 2,091 & 2,734 & 8,037 & 2,734 \\
\hline $\mathrm{Sm}_{2} \mathrm{O}_{3}$ & NA & NA & NA & NA & NA \\
\hline $\mathrm{Sr}$ & 0.002 & 0.005 & 0.002 & NA & 0.002 \\
\hline $\mathrm{Tl}_{2} \mathrm{O}_{3}$ & 0.200 & 0.192 & 0.200 & 0.142 & 0.200 \\
\hline UO & 1,474 & 2,176 & 1,474 & 824 & 1,474 \\
\hline Zno & 0.136 & 0.123 & 0.136 & NA & 0.136 \\
\hline $\mathrm{ZrO}_{2}$ & 0.156 & 0.127 & 0.156 & NA & 0.156 \\
\hline PCB & 261.4 & 234.7 & 261.4 & NA & 261.4 \\
\hline Total CWRG: & 4,590 & 4,690 & 4,590 & 8,942 & 4,590 \\
\hline 1/CWRG, $\mathrm{mg} / \mathrm{m}^{3}:$ & 0.218 & 0.213 & 0.218 & 0.112 & 0.218 \\
\hline
\end{tabular}


Table B-1. CWRG for the PEL-TWA Guideline -- KE Basin General Sludge

\begin{tabular}{|c|c|c|c|c|c|}
\hline Analyte & Weasel Pit & $\begin{array}{c}\text { Main Basin } \\
\text { Floor }\end{array}$ & $\begin{array}{c}\text { Tech View } \\
\text { Pit }\end{array}$ & $\begin{array}{c}\text { North } \\
\text { Loadout Pit }\end{array}$ & Elevator Pit \\
\hline \multicolumn{6}{|c|}{ Percent Contributions to the CWRG for the PEL-TWA Guideline } \\
\hline $\mathrm{Ag}_{2} \mathrm{O}$ & $0.043 \%$ & $0.042 \%$ & $0.043 \%$ & NA & $0.043 \%$ \\
\hline $\mathrm{Al}_{2} \mathrm{O}_{3}$ & $0.159 \%$ & $0.249 \%$ & $0.159 \%$ & $0.043 \%$ & $0.159 \%$ \\
\hline $\mathrm{Am}$ & $0.011 \%$ & $0.080 \%$ & $0.011 \%$ & $0.003 \%$ & $0.011 \%$ \\
\hline $\mathrm{B}_{2} \mathrm{O}_{3}$ & $0.001 \%$ & $0.002 \%$ & $0.001 \%$ & NA & $0.001 \%$ \\
\hline $\mathrm{BaO}$ & $0.019 \%$ & $0.013 \%$ & $0.019 \%$ & $0.004 \%$ & $0.019 \%$ \\
\hline $\mathrm{BeO}$ & $0.570 \%$ & $1.568 \%$ & $0.570 \%$ & $0.242 \%$ & $0.570 \%$ \\
\hline $\mathrm{BiO}$ & $\mathrm{NA}$ & NA & NA & NA & NA \\
\hline $\mathrm{CO}$ & $0.005 \%$ & $0.009 \%$ & $0.005 \%$ & NA & $0.005 \%$ \\
\hline $\mathrm{CaO}$ & $0.081 \%$ & $0.037 \%$ & $0.081 \%$ & $0.022 \%$ & $0.081 \%$ \\
\hline $\mathrm{CdO}$ & $0.253 \%$ & $0.724 \%$ & $0.253 \%$ & $0.309 \%$ & $0.253 \%$ \\
\hline $\mathrm{Cr}_{2} \mathrm{O}_{3}$ & $0.067 \%$ & $0.037 \%$ & $0.067 \%$ & $0.007 \%$ & $0.067 \%$ \\
\hline $\mathrm{CuO}$ & $0.011 \%$ & $0.017 \%$ & $0.011 \%$ & $0.007 \%$ & $0.011 \%$ \\
\hline $\mathrm{Fe}_{2} \mathrm{O}_{3}$ & $1.020 \%$ & $0.776 \%$ & $1.020 \%$ & $0.114 \%$ & $1.020 \%$ \\
\hline $\mathrm{MgO}$ & $0.007 \%$ & $0.006 \%$ & $0.007 \%$ & $0.002 \%$ & $0.007 \%$ \\
\hline $\mathrm{MnO}$ & $0.074 \%$ & $0.074 \%$ & $0.074 \%$ & $0.049 \%$ & $0.074 \%$ \\
\hline $\mathrm{Na}_{2} \mathrm{O}$ & $0.002 \%$ & $0.009 \%$ & $0.002 \%$ & NA & $0.002 \%$ \\
\hline $\mathrm{NiO}$ & NA & NA & $\mathrm{NA}$ & $\mathrm{NA}$ & NA \\
\hline $\mathrm{PO}_{3}$ & NA & NA & NA & $\mathrm{NA}$ & $\mathrm{NA}$ \\
\hline $\mathrm{Pb0}$ & $0.240 \%$ & $0.221 \%$ & $0.240 \%$ & $0.064 \%$ & $0.240 \%$ \\
\hline $\mathrm{Pu}$ & $0.038 \%$ & $0.123 \%$ & $0.038 \%$ & $0.036 \%$ & $0.038 \%$ \\
\hline $\mathrm{Se}$ & $0.022 \%$ & $0.019 \%$ & $0.022 \%$ & NA & $0.022 \%$ \\
\hline $\mathrm{SiO}_{2}$ & $59.56 \%$ & $44.59 \%$ & $59.56 \%$ & $89.88 \%$ & $59.56 \%$ \\
\hline $\mathrm{Sm}_{2} \mathrm{O}_{3}$ & NA & NA & NA & $\mathrm{NA}$ & NA \\
\hline $\mathrm{Sr}$ & $0.000 \%$ & $0.000 \%$ & $0.000 \%$ & NA & $0.000 \%$ \\
\hline $\mathrm{Tl}_{2} \mathrm{O}_{3}$ & $0.004 \%$ & $0.004 \%$ & $0.004 \%$ & $0.002 \%$ & $0.004 \%$ \\
\hline UO & $32.11 \%$ & $46.39 \%$ & $32.11 \%$ & $9.212 \%$ & $32.11 \%$ \\
\hline $\operatorname{Zno}$ & $0.003 \%$ & $0.003 \%$ & $0.003 \%$ & NA & $0.003 \%$ \\
\hline $\mathrm{ZrO}_{2}$ & $0.003 \%$ & $0.003 \%$ & $0.003 \%$ & NA & $0.003 \%$ \\
\hline PCB & $5.695 \%$ & $5.005 \%$ & $5.695 \%$ & NA & $5.695 \%$ \\
\hline
\end{tabular}

Note: The Am and Pu numbers use the PEL-TWA for uranium. 
Table B-2. CWRG for the ERPG-1 Guide1 ine -- KE Bas in Generat S7udge

\begin{tabular}{|c|c|c|c|c|c|}
\hline Analyte & Weasel Pit & $\begin{array}{l}\text { Main Basin } \\
\text { Floor }\end{array}$ & $\begin{array}{c}\text { Tech View } \\
\text { Pit }\end{array}$ & $\begin{array}{c}\text { North } \\
\text { Loadout Pit }\end{array}$ & Elevator Pit \\
\hline \multicolumn{6}{|c|}{ Mass Fractions Divided by the ERPG-1 Gui } \\
\hline $\mathrm{Ag}_{2} \mathrm{O}$ & 0.066 & 0.066 & 0.066 & $N A$ & 0.066 \\
\hline $\mathrm{Al}_{2} \mathrm{O}_{3}$ & 4.871 & 7.801 & 4.871 & 2.544 & 4.871 \\
\hline $\mathrm{Am}$ & 0.043 & 0.311 & 0.043 & 0.022 & 0.043 \\
\hline $\mathrm{B}_{2} \mathrm{O}_{3}$ & 0.016 & 0.029 & 0.016 & $N A$ & 0.016 \\
\hline $\mathrm{BaO}$ & 0.294 & 0.209 & 0.294 & 0.117 & 0.294 \\
\hline $\mathrm{BeO}$ & 5.228 & 14.71 & 5.228 & 4.329 & 5.228 \\
\hline Bio & NA & NA & NA & NA & NA \\
\hline $\mathrm{CO}$ & 0.039 & 0.075 & 0.039 & $\mathrm{NA}$ & 0.039 \\
\hline $\mathrm{CaO}$ & 3.092 & 1.455 & 3.092 & 1.668 & 3.092 \\
\hline $\mathrm{Cd} 0$ & 1.936 & 5.657 & 1.936 & 4.600 & 1.936 \\
\hline $\mathrm{Cr}_{2} \mathrm{O}_{3}$ & 1.032 & 0.571 & 1.032 & 0.220 & 1.032 \\
\hline CuO & 0.168 & 0.272 & 0.168 & 0.216 & 0.168 \\
\hline $\mathrm{Fe}_{2} \mathrm{O}_{3}$ & 31.22 & 24.26 & 31.22 & 6.811 & 31.22 \\
\hline $\mathrm{MgO}$ & 0.111 & 0.099 & 0.111 & 0.056 & 0.111 \\
\hline $\mathrm{MnO}$ & 0.226 & 0.231 & 0.226 & 0.291 & 0.226 \\
\hline $\mathrm{Na}_{2} \mathrm{O}$ & 0.037 & 0.145 & 0.037 & NA & 0.037 \\
\hline $\mathrm{NiO}$ & NA & $N A$ & NA & $N A$ & $N A$ \\
\hline $\mathrm{PO}_{3}$ & $\mathrm{NA}$ & NA & NA & NA & NA \\
\hline $\mathrm{PbO}$ & 3.679 & 3.450 & 3.679 & 1.894 & 3.679 \\
\hline $\mathrm{Pu}$ & 0.147 & 0.481 & 0.147 & 0.271 & 0.147 \\
\hline $\mathrm{Se}$ & 0.335 & 0.297 & 0.335 & $N A$ & 0.335 \\
\hline $\mathrm{SiO}_{2}$ & 911.3 & 697.1 & 911.3 & 2,679 & 911.3 \\
\hline $\mathrm{Sm}_{2} \mathrm{O}_{3}$ & NA & $N A$ & NA & NA & NA \\
\hline $\mathrm{Sr}$ & 0.001 & 0.002 & 0.001 & $\mathrm{NA}$ & 0.001 \\
\hline $\mathrm{Tl}_{2} \mathrm{O}_{3}$ & 0.200 & 0.192 & 0.200 & 0.142 & 0.200 \\
\hline vo & 122.8 & 181.3 & 122.8 & 68.65 & 122.8 \\
\hline $\mathrm{ZnO}$ & 0.090 & 0.082 & 0.090 & $N A$ & 0.090 \\
\hline $\mathrm{ZrO}_{2}$ & 0.078 & 0.063 & 0.078 & NA & 0.078 \\
\hline$P C B$ & 87.13 & 78.25 & 87.13 & NA & 87.13 \\
\hline Total CWRG: & 1,174 & 1,017 & 1,174 & 2,771 & 1,174 \\
\hline $1 /$ CWRG, $\mathrm{mg} / \mathrm{m}^{3}:$ & 0.852 & 0.983 & 0.852 & 0.361 & 0.852 \\
\hline
\end{tabular}


Table B-2. CWRG for the ERPG-1 Guidel ine -- KE Basin General Sludge

\begin{tabular}{|c|c|c|c|c|c|}
\hline Ana7yte & Weasel Pit & $\begin{array}{c}\text { Main Basin } \\
\text { Floor }\end{array}$ & $\begin{array}{c}\text { Tech View } \\
\text { Pit }\end{array}$ & $\begin{array}{c}\text { North } \\
\text { Loadout Pit }\end{array}$ & Elevator Pit \\
\hline \multicolumn{6}{|c|}{ Percent Contributions to the CWRG for the ERPG-1 Guideline } \\
\hline $\mathrm{Ag}_{2} \mathrm{O}$ & $0.006 \%$ & $0.006 \%$ & $0.006 \%$ & NA & $0.006 \%$ \\
\hline $\mathrm{Al}_{2} \mathrm{O}_{3}$ & $0.415 \%$ & $0.767 \%$ & $0.415 \%$ & $0.092 \%$ & $0.415 \%$ \\
\hline Am & $0.004 \%$ & $0.031 \%$ & $0.004 \%$ & $0.001 \%$ & $0.004 \%$ \\
\hline $\mathrm{B}_{2} \mathrm{O}_{3}$ & $0.001 \%$ & $0.003 \%$ & $0.001 \%$ & NA & $0.001 \%$ \\
\hline $\mathrm{BaO}$ & $0.025 \%$ & $0.021 \%$ & $0.025 \%$ & $0.004 \%$ & $0.025 \%$ \\
\hline $\mathrm{Be} 0$ & $0.445 \%$ & $1.446 \%$ & $0.445 \%$ & $0.156 \%$ & $0.445 \%$ \\
\hline $\mathrm{BiO}$ & NA & $N A$ & $N A$ & $N A$ & $N A$ \\
\hline $\mathrm{CO}$ & $0.003 \%$ & $0.007 \%$ & $0.003 \%$ & $\mathrm{NA}$ & $0.003 \%$ \\
\hline $\mathrm{CaO}$ & $0.263 \%$ & $0.143 \%$ & $0.263 \%$ & $0.060 \%$ & $0.263 \%$ \\
\hline $\mathrm{CdO}$ & $0.165 \%$ & $0.556 \%$ & $0.165 \%$ & $0.166 \%$ & $0.165 \%$ \\
\hline $\mathrm{Cr}_{2} \mathrm{O}_{3}$ & $0.088 \%$ & $0.056 \%$ & $0.088 \%$ & $0.008 \%$ & $0.088 \%$ \\
\hline $\mathrm{CuO}$ & $0.014 \%$ & $0.027 \%$ & $0.014 \%$ & $0.008 \%$ & $0.014 \%$ \\
\hline $\mathrm{Fe}_{2} \mathrm{O}_{3}$ & $2.659 \%$ & $2.385 \%$ & $2.659 \%$ & $0.246 \%$ & $2.659 \%$ \\
\hline $\mathrm{MgO}$ & $0.009 \%$ & $0.010 \%$ & $0.009 \%$ & $0.002 \%$ & $0.009 \%$ \\
\hline $\mathrm{MnO}$ & $0.019 \%$ & $0.023 \%$ & $0.019 \%$ & $0.011 \%$ & $0.019 \%$ \\
\hline $\mathrm{Na}_{2} \mathrm{O}$ & $0.003 \%$ & $0.014 \%$ & $0.003 \%$ & NA & $0.003 \%$ \\
\hline $\mathrm{NiO}$ & NA & $N A$ & NA & $\mathrm{NA}$ & $N A$ \\
\hline $\mathrm{PO}_{3}$ & NA & NA & $N A$ & NA & NA \\
\hline $\mathrm{PbO}$ & $0.313 \%$ & $0.339 \%$ & $0.313 \%$ & $0.068 \%$ & $0.313 \%$ \\
\hline $\mathrm{Pu}$ & $0.013 \%$ & $0.047 \%$ & $0.013 \%$ & $0.010 \%$ & $0.013 \%$ \\
\hline $\mathrm{Se}$ & $0.029 \%$ & $0.029 \%$ & $0.029 \%$ & $N A$ & $0.029 \%$ \\
\hline $\mathrm{SiO}_{2}$ & $77.61 \%$ & $68.53 \%$ & $77.61 \%$ & $96.69 \%$ & $77.61 \%$ \\
\hline $\mathrm{Sm}_{2} \mathrm{O}_{3}$ & NA & $N A$ & NA & NA & NA \\
\hline $\mathrm{Sr}$ & $0.000 \%$ & $0.000 \%$ & $0.000 \%$ & NA & $0.000 \%$ \\
\hline $\mathrm{Tl}_{2} \mathrm{O}_{3}$ & $0.017 \%$ & $0.019 \%$ & $0.017 \%$ & $0.005 \%$ & $0.017 \%$ \\
\hline U0 & $10.46 \%$ & $17.83 \%$ & $10.46 \%$ & $2.477 \%$ & $10.46 \%$ \\
\hline $\mathrm{ZnO}$ & $0.008 \%$ & $0.008 \%$ & $0.008 \%$ & NA & $0.008 \%$ \\
\hline $\mathrm{ZrO}_{2}$ & $0.007 \%$ & $0.006 \%$ & $0.007 \%$ & NA & $0.007 \%$ \\
\hline PCB & $7.421 \%$ & $7.693 \%$ & $7.421 \%$ & NA & $7.421 \%$ \\
\hline
\end{tabular}

Note: The $A m$ and $P u$ numbers use the ERPG-l for uranium. 
Table B-3. CWRG for the ERPG-2 Guideline -- KE Basin General S7udge

\begin{tabular}{|c|c|c|c|c|c|}
\hline Ana1yte & Weasel Pit & $\begin{array}{l}\text { Main Basin } \\
\text { Floor }\end{array}$ & $\begin{array}{c}\text { Tech View } \\
\text { Pit }\end{array}$ & $\begin{array}{c}\text { North } \\
\text { Loadout Pit }\end{array}$ & Elevator Pit \\
\hline \multicolumn{6}{|c|}{ Mass Fractions Divided by the ERPG-2 Guidel ine $\left(\mathrm{m}^{3} / \mathrm{g}\right)$} \\
\hline $\mathrm{Ag}_{2} \mathrm{O}$ & 0.039 & 0.040 & 0.039 & NA & 0.039 \\
\hline $\mathrm{Al}_{2} \mathrm{O}_{3}$ & 4.871 & 7.801 & 4.871 & 2.544 & 4.871 \\
\hline $\mathrm{Am}$ & 0.043 & 0.311 & 0.043 & 0.022 & 0.043 \\
\hline $\mathrm{B}_{2} \mathrm{O}_{3}$ & 0.009 & 0.017 & 0.009 & NA & 0.009 \\
\hline $\mathrm{Ba} 0$ & 0.176 & 0.126 & 0.176 & 0.070 & 0.176 \\
\hline $\mathrm{Be} 0$ & 2.091 & 5.883 & 2.091 & 1.732 & 2.091 \\
\hline $\mathrm{BiO}$ & NA & NA & NA & $N A$ & NA \\
\hline $\mathrm{CO}$ & 0.022 & 0.043 & 0.022 & NA & 0.022 \\
\hline $\mathrm{CaO}$ & 1.855 & 0.873 & 1.855 & 1.001 & 1.855 \\
\hline $\mathrm{Cd} 0$ & 0.015 & 0.042 & 0.015 & 0.034 & 0.015 \\
\hline $\mathrm{Cr}_{2} \mathrm{O}_{3}$ & 0.619 & 0.343 & 0.619 & 0.132 & 0.619 \\
\hline $\mathrm{CuO}$ & 0.101 & 0.163 & 0.101 & 0.129 & 0.101 \\
\hline $\mathrm{Fe}_{2} \mathrm{O}_{3}$ & 18.73 & 14.56 & 18.73 & 4.087 & 18.73 \\
\hline $\mathrm{MgO}$ & 0.067 & 0.060 & 0.067 & 0.034 & 0.067 \\
\hline $\mathrm{MnO}$ & 0.135 & 0.139 & 0.135 & 0.175 & 0.135 \\
\hline $\mathrm{Na}_{2} \mathrm{O}$ & 0.022 & 0.087 & 0.022 & $N A$ & 0.022 \\
\hline $\mathrm{NiO}$ & NA & NA & NA & NA & NA \\
\hline $\mathrm{PO}_{3}$ & $\mathrm{NA}$ & $\mathrm{NA}$ & $\mathrm{NA}$ & $\mathrm{NA}$ & $\mathrm{NA}$ \\
\hline $\mathrm{PbO}$ & 2.207 & 2.070 & 2.207 & 1.136 & 2.207 \\
\hline $\mathrm{Pu}$ & 0.147 & 0.481 & 0.147 & 0.271 & 0.147 \\
\hline $\mathrm{Se}$ & 0.201 & 0.178 & 0.201 & NA & 0.201 \\
\hline $\mathrm{SiO}_{2}$ & 546.8 & 418.3 & 546.8 & 1,607 & 546.8 \\
\hline $\mathrm{Sm}_{2} \mathrm{O}_{3}$ & NA & NA & NA & NA & NA \\
\hline $\mathrm{sr}$ & 0.000 & 0.001 & 0.000 & NA & 0.000 \\
\hline $\mathrm{Tl}_{2} \mathrm{O}_{3}$ & 0.200 & 0.192 & 0.200 & 0.142 & 0.200 \\
\hline Uo & 122.8 & 181.3 & 122.8 & 68.65 & 122.8 \\
\hline Zno & 0.090 & 0.082 & 0.090 & $N A$ & 0.090 \\
\hline $\mathrm{ZrO}_{2}$ & 0.031 & 0.025 & 0.031 & $\mathrm{NA}$ & 0.031 \\
\hline $\mathrm{PCB}$ & 52.28 & 46.95 & 52.28 & NA & 52.28 \\
\hline Total CWRG: & 754 & 680 & 754 & 1,688 & 754 \\
\hline $1 / \mathrm{CWRG}, \mathrm{mg} / \mathrm{m}^{3}:$ & 1.327 & 1.470 & 1.327 & 0.593 & 1.327 \\
\hline
\end{tabular}


Table B-3. CWRG for the ERPG-2 Guideline -- KE Basin General Siudge

\begin{tabular}{|c|c|c|c|c|c|}
\hline Analyte & Wease1 Pit & $\begin{array}{c}\text { Main Basin } \\
\text { Floor }\end{array}$ & $\begin{array}{c}\text { Tech View } \\
\text { Pit }\end{array}$ & $\begin{array}{c}\text { North } \\
\text { Loadout Pit }\end{array}$ & Elevator Pit \\
\hline \multicolumn{6}{|c|}{ Percent Contributions to the CWRG for the ERPG-2 Guidel ine } \\
\hline $\mathrm{Ag}_{2} \mathrm{O}$ & $0.005 \%$ & $0.006 \%$ & $0.005 \%$ & NA & $0.005 \%$ \\
\hline $\mathrm{Al}_{2} \mathrm{O}_{3}$ & $0.646 \%$ & $1.147 \%$ & $0.646 \%$ & $0.151 \%$ & $0.646 \%$ \\
\hline $\mathrm{Am}$ & $0.006 \%$ & $0.046 \%$ & $0.006 \%$ & $0.001 \%$ & $0.006 \%$ \\
\hline $\mathrm{B}_{2} \mathrm{O}_{3}$ & $0.001 \%$ & $0.003 \%$ & $0.001 \%$ & NA & $0.001 \%$ \\
\hline $\mathrm{BaO}$ & $0.023 \%$ & $0.018 \%$ & $0.023 \%$ & $0.004 \%$ & $0.023 \%$ \\
\hline $\mathrm{BeO}$ & $0.278 \%$ & $0.865 \%$ & $0.278 \%$ & $0.103 \%$ & $0.278 \%$ \\
\hline $\mathrm{BiO}$ & NA & NA & NA & NA & NA \\
\hline $\mathrm{CO}$ & $0.003 \%$ & $0.006 \%$ & $0.003 \%$ & NA & $0.003 \%$ \\
\hline $\mathrm{CaO}$ & $0.246 \%$ & $0.128 \%$ & $0.246 \%$ & $0.059 \%$ & $0.246 \%$ \\
\hline $\mathrm{CdO}$ & $0.002 \%$ & $0.006 \%$ & $0.002 \%$ & $0.002 \%$ & $0.002 \%$ \\
\hline $\mathrm{Cr}_{2} \mathrm{O}_{3}$ & $0.082 \%$ & $0.050 \%$ & $0.082 \%$ & $0.008 \%$ & $0.082 \%$ \\
\hline CuO & $0.013 \%$ & $0.024 \%$ & $0.013 \%$ & $0.008 \%$ & $0.013 \%$ \\
\hline $\mathrm{Fe}_{2} \mathrm{O}_{3}$ & $2.486 \%$ & $2.141 \%$ & $2.486 \%$ & $0.242 \%$ & $2.486 \%$ \\
\hline $\mathrm{MgO}$ & $0.009 \%$ & $0.009 \%$ & $0.009 \%$ & $0.002 \%$ & $0.009 \%$ \\
\hline MnO & $0.018 \%$ & $0.020 \%$ & $0.018 \%$ & $0.010 \%$ & $0.018 \%$ \\
\hline $\mathrm{Na}_{2} \mathrm{O}$ & $0.003 \%$ & $0.013 \%$ & $0.003 \%$ & NA & $0.003 \%$ \\
\hline $\mathrm{NiO}$ & NA & NA & NA & NA & NA \\
\hline $\mathrm{PO}_{3}$ & NA & NA & NA & NA & NA \\
\hline $\mathrm{Pb0}$ & $0.293 \%$ & $0.304 \%$ & $0.293 \%$ & $0.067 \%$ & $0.293 \%$ \\
\hline $\mathrm{Pu}$ & $0.020 \%$ & $0.071 \%$ & $0.020 \%$ & $0.016 \%$ & $0.020 \%$ \\
\hline $\mathrm{Se}$ & $0.027 \%$ & $0.026 \%$ & $0.027 \%$ & NA & $0.027 \%$ \\
\hline $\mathrm{SiO}_{2}$ & $72.56 \%$ & $61.50 \%$ & $72.56 \%$ & $95.25 \%$ & $72.56 \%$ \\
\hline $\mathrm{Sm}_{2} \mathrm{O}_{3}$ & NA & NA & NA & NA & $N A$ \\
\hline $\mathrm{Sr}$ & $0.000 \%$ & $0.000 \%$ & $0.000 \%$ & NA & $0.000 \%$ \\
\hline $\mathrm{T1}_{2} \mathrm{O}_{3}$ & $0.027 \%$ & $0.028 \%$ & $0.027 \%$ & $0.008 \%$ & $0.027 \%$ \\
\hline UO & $16.30 \%$ & $26.66 \%$ & $16.30 \%$ & $4.068 \%$ & $16.30 \%$ \\
\hline $\mathrm{ZnO}$ & $0.012 \%$ & $0.012 \%$ & $0.012 \%$ & NA & $0.012 \%$ \\
\hline $\mathrm{ZrO}_{2}$ & $0.004 \%$ & $0.004 \%$ & $0.004 \%$ & $N A$ & $0.004 \%$ \\
\hline$P C B$ & $6.938 \%$ & $6.904 \%$ & $6.938 \%$ & NA & $6.938 \%$ \\
\hline
\end{tabular}

Note: The $A m$ and $P u$ numbers use the ERPG-2 for uranium. 
Table B-4. CWRG for the ERPG-3 Guideline -- KE Basin General Sludge

\begin{tabular}{|c|c|c|c|c|c|}
\hline Analyte & Weasel Pit & $\begin{array}{c}\text { Main Basin } \\
\text { Floor }\end{array}$ & $\begin{array}{c}\text { Tech View } \\
\text { Pit }\end{array}$ & $\begin{array}{c}\text { North } \\
\text { Loadout Pit } \\
\end{array}$ & Elevator Pit \\
\hline \multicolumn{6}{|c|}{ Mass Fractions Divided by the ERPG-3 Guidel ine $\left(\mathrm{m}^{3} / \mathrm{g}\right)$} \\
\hline $\mathrm{Ag}_{2} \mathrm{O}$ & 0.002 & 0.002 & 0.002 & $N A$ & 0.002 \\
\hline $\mathrm{Al}_{2} \mathrm{O}_{3}$ & 2.923 & 4.680 & 2.923 & 1.526 & 2.923 \\
\hline Am & 0.0026 & 0.0187 & 0.0026 & 0.0013 & 0.0026 \\
\hline $\mathrm{B}_{2} \mathrm{O}_{3}$ & 0.002 & 0.003 & 0.002 & NA & 0.002 \\
\hline $\mathrm{BaO}$ & 0.035 & 0.025 & 0.035 & 0.014 & 0.035 \\
\hline $\mathrm{Be} 0$ & 0.523 & 1.471 & 0.523 & 0.433 & 0.523 \\
\hline $\mathrm{BiO}$ & $N A$ & $N A$ & $N A$ & $N A$ & NA \\
\hline CO & 0.015 & 0.030 & 0.015 & NA & 0.015 \\
\hline $\mathrm{CaO}$ & 0.742 & 0.349 & 0.742 & 0.400 & 0.742 \\
\hline $\mathrm{Cd} 0$ & 0.006 & 0.019 & 0.006 & 0.015 & 0.006 \\
\hline $\mathrm{Cr}_{2} \mathrm{O}_{3}$ & 0.062 & 0.034 & 0.062 & 0.013 & 0.062 \\
\hline CuO & 0.005 & 0.008 & 0.005 & 0.006 & 0.005 \\
\hline $\mathrm{Fe}_{2} \mathrm{O}_{3}$ & 0.187 & 0.146 & 0.187 & 0.041 & 0.187 \\
\hline $\mathrm{MgO}$ & 0.013 & 0.012 & 0.013 & 0.007 & 0.013 \\
\hline $\mathrm{MnO}$ & 0.0014 & 0.0014 & 0.0014 & 0.0017 & 0.0014 \\
\hline $\mathrm{Na}_{2} \mathrm{O}$ & 0.0045 & 0.0173 & 0.0045 & NA & 0.0045 \\
\hline $\mathrm{NiO}$ & NA & $N A$ & NA & NA & NA \\
\hline $\mathrm{PO}_{3}$ & $\mathrm{NA}$ & NA & NA & $\mathrm{NA}$ & $N A$ \\
\hline $\mathrm{PbO}$ & 0.0055 & 0.0052 & 0.0055 & 0.0028 & 0.0055 \\
\hline $\mathrm{Pu}$ & 0.0088 & 0.0288 & 0.0088 & 0.0162 & 0.0088 \\
\hline $\mathrm{Se}$ & 0.201 & 0.178 & 0.201 & NA & 0.201 \\
\hline $\mathrm{SiO}_{2}$ & 10.935 & 8.365 & 10.935 & 32.149 & 10.935 \\
\hline $\mathrm{Sm}_{2} \mathrm{O}_{3}$ & NA & NA & NA & NA & NA \\
\hline $\mathrm{sr}$ & 0.0000 & 0.0001 & 0.0000 & NA & 0.0000 \\
\hline $\mathrm{Tl}_{2} \mathrm{O}_{3}$ & 0.020 & 0.019 & 0.020 & 0.014 & 0.020 \\
\hline UO & 7.368 & 10.88 & 7.368 & 4.119 & 7.368 \\
\hline $\mathrm{ZnO}$ & 0.0027 & 0.0025 & 0.0027 & $N A$ & 0.0027 \\
\hline $\mathrm{ZrO}_{2}$ & 0.016 & 0.013 & 0.016 & NA & 0.016 \\
\hline $\mathrm{PCB}$ & 0.0005 & 0.0005 & 0.0005 & NA & 0.0005 \\
\hline Total CWRG: & 23.1 & 26.3 & 23.1 & 38.8 & 23.1 \\
\hline $1 / \mathrm{CWRG}, \mathrm{mg} / \mathrm{m}^{3}:$ & 43.3 & 38.0 & 43.3 & 25.8 & 43.3 \\
\hline
\end{tabular}


Table B-4. CWRG for the ERPG-3 Guideline -- KE Basin General S7udge

\begin{tabular}{|c|c|c|c|c|c|}
\hline Analyte & Weasel Pit & $\begin{array}{c}\text { Main Basin } \\
\text { Floor }\end{array}$ & $\begin{array}{c}\text { Tech View } \\
\text { Pit }\end{array}$ & $\begin{array}{c}\text { North } \\
\text { Loadout Pit }\end{array}$ & Elevator Pit \\
\hline \multicolumn{6}{|c|}{ Percent Contributions to the CWRG for the ERPG-3 Guideline } \\
\hline $\mathrm{Ag}_{2} \mathrm{O}$ & $0.009 \%$ & $0.008 \%$ & $0.009 \%$ & NA & $0.009 \%$ \\
\hline $\mathrm{Al}_{2} \mathrm{O}_{3}$ & $12.66 \%$ & $17.79 \%$ & $12.66 \%$ & $3.938 \%$ & $12.66 \%$ \\
\hline Am & $0.011 \%$ & $0.071 \%$ & $0.011 \%$ & $0.003 \%$ & $0.011 \%$ \\
\hline $\mathrm{B}_{2} \mathrm{O}_{3}$ & $0.008 \%$ & $0.013 \%$ & $0.008 \%$ & NA & $0.008 \%$ \\
\hline $\mathrm{BaO}$ & $0.153 \%$ & $0.095 \%$ & $0.153 \%$ & $0.036 \%$ & $0.153 \%$ \\
\hline $\mathrm{Be} 0$ & $2.265 \%$ & $5.590 \%$ & $2.265 \%$ & $1.117 \%$ & $2.265 \%$ \\
\hline BiO & NA & NA & $N A$ & NA & NA \\
\hline $\mathrm{CO}$ & $0.067 \%$ & $0.114 \%$ & $0.067 \%$ & NA & $0.067 \%$ \\
\hline $\mathrm{CaO}$ & $3.215 \%$ & $1.327 \%$ & $3.215 \%$ & $1.033 \%$ & $3.215 \%$ \\
\hline $\mathrm{Cd} 0$ & $0.028 \%$ & $0.072 \%$ & $0.028 \%$ & $0.040 \%$ & $0.028 \%$ \\
\hline $\mathrm{Cr}_{2} \mathrm{O}_{3}$ & $0.268 \%$ & $0.130 \%$ & $0.268 \%$ & $0.034 \%$ & $0.268 \%$ \\
\hline $\mathrm{CuO}$ & $0.022 \%$ & $0.031 \%$ & $0.022 \%$ & $0.017 \%$ & $0.022 \%$ \\
\hline $\mathrm{Fe}_{2} \mathrm{O}_{3}$ & $0.811 \%$ & $0.553 \%$ & $0.811 \%$ & $0.105 \%$ & $0.811 \%$ \\
\hline $\mathrm{MgO}$ & $0.058 \%$ & $0.045 \%$ & $0.058 \%$ & $0.017 \%$ & $0.058 \%$ \\
\hline $\mathrm{MnO}$ & $0.006 \%$ & $0.005 \%$ & $0.006 \%$ & $0.005 \%$ & $0.006 \%$ \\
\hline $\mathrm{Na}_{2} \mathrm{O}$ & $0.019 \%$ & $0.066 \%$ & $0.019 \%$ & $N A$ & $0.019 \%$ \\
\hline $\mathrm{NiO}$ & NA & NA & NA & NA & NA \\
\hline $\mathrm{PO}_{3}$ & NA & NA & $N A$ & $\mathrm{NA}$ & $\mathrm{NA}$ \\
\hline $\mathrm{PbO}$ & $0.024 \%$ & $0.020 \%$ & $0.024 \%$ & $0.007 \%$ & $0.024 \%$ \\
\hline $\mathrm{Pu}$ & $0.038 \%$ & $0.110 \%$ & $0.038 \%$ & $0.042 \%$ & $0.038 \%$ \\
\hline $\mathrm{Se}$ & $0.871 \%$ & $0.677 \%$ & $0.871 \%$ & NA & $0.871 \%$ \\
\hline $\mathrm{SiO}_{2}$ & $47.38 \%$ & $31.80 \%$ & $47.38 \%$ & $82.94 \%$ & $47.38 \%$ \\
\hline $\mathrm{Sm}_{2} \mathrm{O}_{3}$ & NA & $N A$ & NA & NA & NA \\
\hline $\mathrm{Sr}$ & $0.000 \%$ & $0.000 \%$ & $0.000 \%$ & NA & $0.000 \%$ \\
\hline $\mathrm{Tl}_{2} \mathrm{O}_{3}$ & $0.087 \%$ & $0.073 \%$ & $0.087 \%$ & $0.037 \%$ & $0.087 \%$ \\
\hline 40 & $31.92 \%$ & $41.35 \%$ & $31.92 \%$ & $10.63 \%$ & $31.92 \%$ \\
\hline $\mathrm{ZnO}$ & $0.012 \%$ & $0.009 \%$ & $0.012 \%$ & NA & $0.012 \%$ \\
\hline $\mathrm{ZrO}_{2}$ & $0.068 \%$ & $0.048 \%$ & $0.068 \%$ & $\mathrm{NA}$ & $0.068 \%$ \\
\hline PCB & $0.002 \%$ & $0.002 \%$ & $0.002 \%$ & $N A$ & $0.002 \%$ \\
\hline
\end{tabular}

Note: The Am and Pu numbers use the ERPG-3 for uranium. 
Table B-5. CWRG for the PEL-TWA Guideline -- KE Basin Canister and Fuel Wash Sludge

\begin{tabular}{|c|c|c|c|c|c|}
\hline \multirow[b]{2}{*}{ Analyte } & \multicolumn{2}{|c|}{ Canister Sludge } & \multicolumn{3}{|c|}{ Fuel Washing Sludge } \\
\hline & Full & Empty & Internal & Coating & Pieces \\
\hline \multicolumn{6}{|c|}{ Mass Fractions Divided by the PEL-TWA Guideline $(\mathrm{m} 3 / \mathrm{g})$} \\
\hline $\mathrm{Ag}_{2} \mathrm{O}$ & 10.632 & 10.632 & NA & NA & NA \\
\hline $\mathrm{Al}_{2} \mathrm{O}_{3}$ & 19.233 & 19.23 & 1.095 & 22.06 & NA \\
\hline $\mathrm{Am}$ & 2.419 & 2.419 & 0.633 & 0.033 & 0.146 \\
\hline $\mathrm{B}_{2} \mathrm{O}_{3}$ & 0.106 & 0.106 & NA & NA & NA \\
\hline $\mathrm{BaO}$ & 0.366 & 0.366 & NA & $N A$ & $N A$ \\
\hline $\mathrm{BeO}$ & 111.98 & 111.98 & NA & NA & NA \\
\hline $\mathrm{BiO}$ & NA & NA & NA & NA & NA \\
\hline $\mathrm{CO}$ & 0.281 & 0.281 & 0.082 & NA & 0.018 \\
\hline $\mathrm{CaO}$ & 0.367 & 0.367 & NA & 3.072 & NA \\
\hline CdO & 19.00 & 19.00 & NA & NA & NA \\
\hline $\mathrm{Cr}_{2} \mathrm{O}_{3}$ & 1.305 & 1.305 & NA & NA & NA \\
\hline CuO & 0.544 & 0.544 & NA & NA & NA \\
\hline $\mathrm{Fe}_{2} \mathrm{O}_{3}$ & 12.37 & 12.37 & 0.187 & 2.95 & NA \\
\hline $\mathrm{MgO}$ & 0.266 & 0.266 & NA & $N A$ & NA \\
\hline $\mathrm{MnO}$ & 2.579 & 2.579 & NA & NA & $N A$ \\
\hline $\mathrm{Na}_{2} \mathrm{O}$ & 0.091 & 0.091 & NA & NA & NA \\
\hline $\mathrm{NiO}$ & 0.286 & 0.286 & NA & NA & NA \\
\hline $\mathrm{PO}_{3}$ & 2.281 & 2.281 & NA & $N A$ & NA \\
\hline $\mathrm{PbO}$ & 9.343 & 9.343 & NA & NA & NA \\
\hline $\mathrm{Pu}$ & 34.75 & 34.75 & 74.85 & 37.03 & 63.23 \\
\hline $\mathrm{Se}$ & NA & NA & NA & NA & NA \\
\hline $\mathrm{SiO}_{2}$ & 444 & 444 & 1502.8 & NA & $N A$ \\
\hline $\mathrm{Sm}_{2} \mathrm{O}_{3}$ & NA & NA & NA & NA & NA \\
\hline $\mathrm{Sr}$ & 0.002 & 0.002 & 0.001 & 0.000 & 0.000 \\
\hline $\mathrm{Tl}_{2} \mathrm{O}_{3}$ & NA & NA & NA & NA & NA \\
\hline UO & 12,027 & 12,027 & 16,442 & 13893.3 & 18,512 \\
\hline $\mathrm{ZnO}$ & 0.067 & 0.067 & NA & NA & NA \\
\hline $\mathrm{ZrO}_{2}$ & 0.112 & 0.112 & $\mathrm{NA}$ & $N A$ & 13.05 \\
\hline$P C B$ & 2.036 & 2.036 & NA & NA & NA \\
\hline Total CWRG: & 12,701 & 12,701 & 18,022 & 13,958 & 18,588 \\
\hline $\mathrm{I} / \mathrm{CWRG}, \mathrm{mg} / \mathrm{m}^{3}:$ & 0.079 & 0.079 & 0.055 & 0.072 & 0.054 \\
\hline
\end{tabular}


Table B-5. CWRG for the PEL-TWA Guideline -- KE Basin Canister and Fuel Wash Sludge

\begin{tabular}{|c|c|c|c|c|c|}
\hline \multirow{2}{*}{ Ana1yte } & \multicolumn{2}{|c|}{ Canister S7udge } & \multicolumn{3}{|c|}{ Fuel Washing STudge } \\
\hline & Ful1 & Empty & Internal & Coating & Pieces \\
\hline \multicolumn{6}{|c|}{ Percent Contributions to the CWRG for the PEL-TWA Guidel ine } \\
\hline $\mathrm{Ag}_{2} \mathrm{O}$ & $0.084 \%$ & $0.084 \%$ & NA & NA & NA \\
\hline $\mathrm{Al}_{2} \mathrm{O}_{3}$ & $0.151 \%$ & $0.151 \%$ & $0.006 \%$ & $0.158 \%$ & NA \\
\hline Am & $0.019 \%$ & $0.019 \%$ & $0.004 \%$ & $0.000 \%$ & $0.001 \%$ \\
\hline $\mathrm{B}_{2} \mathrm{O}_{3}$ & $0.001 \%$ & $0.001 \%$ & NA & NA & NA \\
\hline $\mathrm{Ba} 0$ & $0.003 \%$ & $0.003 \%$ & NA & $\mathrm{NA}$ & $N A$ \\
\hline $\mathrm{Be} 0$ & $0.882 \%$ & $0.882 \%$ & $\mathrm{NA}$ & $\mathrm{NA}$ & $\mathrm{NA}$ \\
\hline $\mathrm{BiO}$ & NA & NA & $N A$ & $\mathrm{NA}$ & $\mathrm{NA}$ \\
\hline $\mathrm{CO}$ & $0.002 \%$ & $0.002 \%$ & $0.000 \%$ & $\mathrm{NA}$ & $0.000 \%$ \\
\hline $\mathrm{CaO}$ & $0.003 \%$ & $0.003 \%$ & NA & $0.022 \%$ & NA \\
\hline $\mathrm{CdO}$ & $0.150 \%$ & $0.150 \%$ & $N A$ & NA & $N A$ \\
\hline $\mathrm{Cr}_{2} \mathrm{O}_{3}$ & $0.010 \%$ & $0.010 \%$ & NA & $\mathrm{NA}$ & $\mathrm{NA}$ \\
\hline CuO & $0.004 \%$ & $0.004 \%$ & $\mathrm{NA}$ & $N A$ & $N A$ \\
\hline $\mathrm{Fe}_{2} \mathrm{O}_{3}$ & $0.097 \%$ & $0.097 \%$ & $0.001 \%$ & $0.021 \%$ & NA \\
\hline MgO & $0.002 \%$ & $0.002 \%$ & $N A$ & NA & NA \\
\hline $\mathrm{MnO}$ & $0.020 \%$ & $0.020 \%$ & $\mathrm{NA}$ & NA & $N A$ \\
\hline $\mathrm{Na}_{2} \mathrm{O}$ & $0.001 \%$ & $0.001 \%$ & $N A$ & $\mathrm{NA}$ & $N A$ \\
\hline $\mathrm{NiO}$ & $0.002 \%$ & $0.002 \%$ & NA & NA & $\mathrm{NA}$ \\
\hline $\mathrm{PO}_{3}$ & $0.018 \%$ & $0.018 \%$ & $N A$ & NA & NA \\
\hline $\mathrm{PbO}$ & $0.074 \%$ & $0.074 \%$ & NA & $N A$ & NA \\
\hline $\mathrm{Pu}$ & $0.274 \%$ & $0.274 \%$ & $0.415 \%$ & $0.265 \%$ & $0.340 \%$ \\
\hline $\mathrm{Se}$ & NA & NA & NA & NA & $\mathrm{NA}$ \\
\hline $\mathrm{SiO}_{2}$ & $3.50 \%$ & $3.50 \%$ & $8.34 \%$ & NA & $\mathrm{NA}$ \\
\hline $\mathrm{Sm}_{2} \mathrm{O}_{3}$ & NA & NA & NA & NA & NA \\
\hline $\mathrm{Sr}$ & $0.000 \%$ & $0.000 \%$ & $0.000 \%$ & $0.000 \%$ & $0.000 \%$ \\
\hline $\mathrm{Tl}_{2} \mathrm{O}_{3}$ & $\mathrm{NA}$ & NA & $\mathrm{NA}$ & $\mathrm{NA}$ & NA \\
\hline U0 & $94.69 \%$ & $94.69 \%$ & $91.23 \%$ & $99.53 \%$ & $99.59 \%$ \\
\hline $\mathrm{ZnO}$ & $0.001 \%$ & $0.001 \%$ & NA & NA & NA \\
\hline $\mathrm{ZrO}_{2}$ & $0.001 \%$ & $0.001 \%$ & NA & NA & $0.070 \%$ \\
\hline PCB & $0.016 \%$ & $0.016 \%$ & NA & NA & NA \\
\hline
\end{tabular}

Note: The Am and $\mathrm{Pu}$ numbers use the PEL-TWA for uranium. 
Table B-6. CWRG for the ERPG-1 Guide1ine -- KE Basin Canister and Fue1 Wash S7udge

\begin{tabular}{|c|c|c|c|c|c|}
\hline \multirow[b]{2}{*}{ Analyte } & \multicolumn{2}{|c|}{ Canister Sludge } & \multicolumn{3}{|c|}{ Fuel Washing Sludge } \\
\hline & Fu11 & Empty & Internal & Coating & Pieces \\
\hline \multicolumn{6}{|c|}{ Mass Fractions Divided by the ERPG-1 Guide 1 ine $\left(\mathrm{m}^{3} / \mathrm{g}\right)$} \\
\hline $\mathrm{Ag}_{2} \mathrm{O}$ & 0.354 & 0.354 & NA & NA & NA \\
\hline $\mathrm{Al}_{2} \mathrm{O}_{3}$ & 12.82 & 12.82 & 0.730 & 14.71 & NA \\
\hline Am & 0.202 & 0.202 & 0.053 & 0.003 & 0.012 \\
\hline $\mathrm{B}_{2} \mathrm{O}_{3}$ & 0.035 & 0.035 & NA & NA & NA \\
\hline $\mathrm{Ba} 0$ & 0.122 & 0.122 & NA & NA & NA \\
\hline $\mathrm{Be} 0$ & 22.40 & 22.40 & NA & NA & NA \\
\hline BiO & NA & NA & NA & NA & NA \\
\hline CO & 0.049 & 0.049 & 0.014 & NA & 0.003 \\
\hline $\mathrm{CaO}$ & 0.306 & 0.306 & NA & 2.560 & NA \\
\hline $\mathrm{Cd} 0$ & 3.167 & 3.167 & NA & NA & NA \\
\hline $\mathrm{Cr}_{2} \mathrm{O}_{3}$ & 0.435 & 0.435 & NA & NA & NA \\
\hline $\mathrm{CuO}$ & 0.181 & 0.181 & NA & NA & NA \\
\hline $\mathrm{Fe}_{2} \mathrm{O}_{3}$ & 8.249 & 8.249 & 0.125 & 1.969 & $\mathrm{NA}$ \\
\hline $\mathrm{MgO}$ & 0.089 & 0.089 & NA & $N A$ & NA \\
\hline Mno & 0.172 & 0.172 & $\mathrm{NA}$ & NA & NA \\
\hline $\mathrm{Na}_{3} \mathrm{O}$ & 0.030 & 0.030 & NA & NA & $\mathrm{NA}$ \\
\hline $\mathrm{NiO}$ & 0.095 & 0.095 & NA & NA & $\mathrm{NA}$ \\
\hline $\mathrm{PO}_{3}$ & 0.760 & 0.760 & NA & NA & NA \\
\hline $\mathrm{PbO}$ & 3.114 & 3.114 & NA & NA & $\mathrm{NA}$ \\
\hline $\mathrm{Pu}$ & 2.896 & 2.896 & 6.238 & 3.086 & 5.269 \\
\hline $\mathrm{Se}$ & NA & NA & NA & NA & NA \\
\hline $\mathrm{SiO}_{2}$ & 148.0 & 148.0 & 500.9 & $\mathrm{NA}$ & NA \\
\hline $\mathrm{Sm}_{2} \mathrm{O}_{3}$ & NA & NA & NA & NA & $\mathrm{NA}$ \\
\hline $\mathrm{sr}$ & 0.001 & 0.001 & 0.000 & 0.000 & 0.000 \\
\hline $\mathrm{Tl}_{2} \mathrm{O}_{3}$ & $\mathrm{NA}$ & $\mathrm{NA}$ & $\mathrm{NA}$ & NA & $\mathrm{NA}$ \\
\hline Uo & 1,002 & 1,002 & 1,370 & 1,158 & 1,543 \\
\hline $\mathrm{ZnO}$ & 0.044 & 0.044 & NA & NA & NA \\
\hline $\mathrm{ZrO}_{2}$ & 0.056 & 0.056 & $\mathrm{NA}$ & NA & 6.523 \\
\hline PCB & 0.679 & 0.679 & $N A$ & $\mathrm{NA}$ & $N A$ \\
\hline Total CWRG: & 1,207 & 1,207 & 1,878 & 1,180 & 1,554 \\
\hline $1 / \mathrm{CWRG}, \mathrm{mg} / \mathrm{m}^{3}:$ & 0.829 & 0.829 & 0.532 & 0.847 & 0.643 \\
\hline
\end{tabular}


Table B-6. CWRG for the ERPG-1 Guideline -- KE Basin Canister and Fuel Wash STudge

\begin{tabular}{|c|c|c|c|c|c|}
\hline \multirow[b]{2}{*}{ Analyte } & \multicolumn{2}{|c|}{ Canister Sludge } & \multicolumn{3}{|c|}{ Fue] Washing Sludge } \\
\hline & Ful1 & Empty & Internal & Coating & Pieces \\
\hline \multicolumn{6}{|c|}{ Percent Contributions to the CWRG for the ERPG-1 Guideline } \\
\hline $\mathrm{Ag}_{2} \mathrm{O}$ & $0.029 \%$ & $0.029 \%$ & NA & NA & NA \\
\hline $\mathrm{Al}_{2} \mathrm{O}_{3}$ & $1.063 \%$ & $1.063 \%$ & $0.039 \%$ & $1.246 \%$ & NA \\
\hline Am & $0.017 \%$ & $0.017 \%$ & $0.003 \%$ & $0.000 \%$ & $0.001 \%$ \\
\hline $\mathrm{B}_{2} \mathrm{O}_{3}$ & $0.003 \%$ & $0.003 \%$ & $N A$ & $N A$ & NA \\
\hline $\mathrm{BaO}$ & $0.010 \%$ & $0.010 \%$ & NA & NA & NA \\
\hline $\mathrm{Be} 0$ & $1.856 \%$ & $1.856 \%$ & NA & NA & NA \\
\hline BiO & NA & $N A$ & NA & NA & NA \\
\hline $\mathrm{CO}$ & $0.004 \%$ & $0.004 \%$ & $0.001 \%$ & NA & $0.000 \%$ \\
\hline $\mathrm{CaO}$ & $0.025 \%$ & $0.025 \%$ & $N A$ & $0.217 \%$ & NA \\
\hline $\mathrm{CdO}$ & $0.262 \%$ & $0.262 \%$ & NA & NA & NA \\
\hline $\mathrm{Cr}_{2} \mathrm{O}_{3}$ & $0.036 \%$ & $0.036 \%$ & NA & $N A$ & $\mathrm{NA}$ \\
\hline CuO & $0.015 \%$ & $0.015 \%$ & $N A$ & NA & $N A$ \\
\hline $\mathrm{Fe}_{2} \mathrm{O}_{3}$ & $0.684 \%$ & $0.684 \%$ & $0.007 \%$ & $0.167 \%$ & $N A$ \\
\hline $\mathrm{MgO}$ & $0.007 \%$ & $0.007 \%$ & NA & NA & $N A$ \\
\hline $\mathrm{MnO}$ & $0.014 \%$ & $0.014 \%$ & NA & NA & NA \\
\hline $\mathrm{Na}_{2} \mathrm{O}$ & $0.003 \%$ & $0.003 \%$ & $N A$ & NA & NA \\
\hline $\mathrm{NiO}$ & $0.008 \%$ & $0.008 \%$ & $N A$ & NA & NA \\
\hline $\mathrm{PO}_{3}$ & $0.063 \%$ & $0.063 \%$ & NA & NA & NA \\
\hline $\mathrm{PbO}$ & $0.258 \%$ & $0.258 \%$ & NA & NA & NA \\
\hline $\mathrm{Pu}$ & $0.240 \%$ & $0.240 \%$ & $0.332 \%$ & $0.261 \%$ & $0.339 \%$ \\
\hline $\mathrm{Se}$ & NA & NA & NA & NA & NA \\
\hline $\mathrm{SiO}_{2}$ & $12.27 \%$ & $12.27 \%$ & $26.67 \%$ & NA & $N A$ \\
\hline $\mathrm{Sm}_{2} \mathrm{O}_{3}$ & NA & NA & NA & NA & NA \\
\hline$S r$ & $0.000 \%$ & $0.000 \%$ & $0.000 \%$ & $0.000 \%$ & $0.000 \%$ \\
\hline $\mathrm{Tl}_{2} \mathrm{O}_{3}$ & NA & NA & NA & NA & NA \\
\hline UO & $83.07 \%$ & $83.07 \%$ & $72.95 \%$ & $98.11 \%$ & $99.24 \%$ \\
\hline $\mathrm{ZnO}$ & $0.004 \%$ & $0.004 \%$ & NA & $N A$ & NA \\
\hline $\mathrm{ZrO}_{2}$ & $0.005 \%$ & $0.005 \%$ & NA & NA & $0.420 \%$ \\
\hline PCB & $0.056 \%$ & $0.056 \%$ & NA & NA & NA \\
\hline
\end{tabular}

Note: The Am and Pu numbers use the ERPG-1 for uranium. 
Table B-7. CWRG for the ERPG-2 Guideline -- KE Basin Canister and Fuel Wash sludge

\begin{tabular}{|c|c|c|c|c|c|}
\hline \multirow[b]{2}{*}{ Analyte } & \multicolumn{2}{|c|}{ Canister Sludge } & \multicolumn{3}{|c|}{ Fuel Washing Sludge } \\
\hline & Fu11 & Empty & Internal & Coating & Pieces \\
\hline \multicolumn{6}{|c|}{ Mass Fractions Divided by the ERPG-2 Guideline $(\mathrm{m} 3 / \mathrm{g})$} \\
\hline $\mathrm{Ag}_{2} \mathrm{O}$ & 0.213 & 0.213 & NA & NA & NA \\
\hline $\mathrm{Al}_{2} \mathrm{O}_{3}$ & 12.82 & 12.82 & 0.730 & 14.71 & NA \\
\hline $\mathrm{Am}$ & 0.202 & 0.202 & 0.053 & 0.003 & 0.012 \\
\hline $\mathrm{B}_{2} \mathrm{O}_{3}$ & 0.021 & 0.021 & $\mathrm{NA}$ & $\mathrm{NA}$ & NA \\
\hline $\mathrm{BaO}$ & 0.073 & 0.073 & NA & NA & NA \\
\hline $\mathrm{BeO}$ & 8.958 & 8.958 & NA & NA & NA \\
\hline $\mathrm{BiO}$ & NA & NA & NA & NA & NA \\
\hline $\mathrm{CO}$ & 0.028 & 0.028 & 0.008 & NA & 0.002 \\
\hline $\mathrm{CaO}$ & 0.184 & 0.184 & NA & 1.536 & NA \\
\hline $\mathrm{CdO}$ & 0.024 & 0.024 & NA & NA & $N A$ \\
\hline $\mathrm{Cr}_{2} \mathrm{O}_{3}$ & 0.261 & 0.261 & $N A$ & $N A$ & $\mathrm{NA}$ \\
\hline CuO & 0.109 & 0.109 & NA & NA & NA \\
\hline $\mathrm{Fe}_{2} \mathrm{O}_{3}$ & 4.950 & 4.950 & 0.075 & 1.181 & NA \\
\hline $\mathrm{MgO}$ & 0.053 & 0.053 & NA & NA & $\mathrm{NA}$ \\
\hline MnO & 0.103 & 0.103 & NA & NA & NA \\
\hline $\mathrm{Na}_{2} \mathrm{O}$ & 0.018 & 0.018 & NA & NA & NA \\
\hline $\mathrm{NiO}$ & 0.057 & 0.057 & NA & NA & NA \\
\hline $\mathrm{PO}_{3}$ & 0.023 & 0.023 & NA & NA & NA \\
\hline Pb0 & 1.869 & 1.869 & NA & NA & $N A$ \\
\hline $\mathrm{Pu}$ & 2.896 & 2.896 & 6.238 & 3.086 & 5.269 \\
\hline $\mathrm{Se}$ & NA & $N A$ & NA & NA & NA \\
\hline $\mathrm{SiO}_{2}$ & 88.8 & 88.8 & 300.6 & NA & NA \\
\hline $\mathrm{Sm}_{2} \mathrm{O}_{3}$ & NA & NA & NA & NA & NA \\
\hline $\mathrm{Sr}$ & 0.000 & 0.000 & 0.000 & 0.000 & 0.000 \\
\hline $\mathrm{Tl}_{2} \mathrm{O}_{3}$ & NA & NA & $N A$ & $N A$ & NA \\
\hline U0 & 1,002 & 1,002 & 1,370 & 1,158 & 1,543 \\
\hline $\mathrm{ZnO}$ & 0.044 & 0.044 & NA & NA & NA \\
\hline $\mathrm{ZrO}_{2}$ & 0.022 & 0.022 & NA & NA & 2.609 \\
\hline PCB & 0.407 & 0.407 & NA & NA & NA \\
\hline Total CWRG: & 1,124 & 1,124 & 1,678 & 1,178 & 1,551 \\
\hline $1 / \mathrm{CWRG}, \mathrm{mg} / \mathrm{m}^{3}:$ & 0.889 & 0.889 & 0.596 & 0.849 & 0.645 \\
\hline
\end{tabular}


Table B-7. CWRG for the ERPG-2 Guideline -- KE Basin Canister and Fuel Wash STudge

\begin{tabular}{|c|c|c|c|c|c|}
\hline \multirow[b]{2}{*}{ Analyte } & \multicolumn{2}{|c|}{ Canister STudge } & \multicolumn{3}{|c|}{ Fuel Washing Sludge } \\
\hline & Full & Empty & Internal & Coating & Pieces \\
\hline \multicolumn{6}{|c|}{ Percent Contributions to the CWRG for the ERPG-2 Guideline } \\
\hline $\mathrm{Ag}_{2} \mathrm{O}$ & $0.019 \%$ & $0.019 \%$ & NA & NA & NA \\
\hline $\mathrm{Al}_{2} \mathrm{O}_{3}$ & $1.140 \%$ & $1.140 \%$ & $0.044 \%$ & $1.248 \%$ & NA \\
\hline $\mathrm{Am}$ & $0.018 \%$ & $0.018 \%$ & $0.003 \%$ & $0.000 \%$ & $0.001 \%$ \\
\hline $\mathrm{B}_{2} \mathrm{O}_{3}$ & $0.002 \%$ & $0.002 \%$ & NA & NA & NA \\
\hline $\mathrm{Ba} 0$ & $0.007 \%$ & $0.007 \%$ & NA & $N A$ & NA \\
\hline $\mathrm{BeO}$ & $0.797 \%$ & $0.797 \%$ & NA & NA & NA \\
\hline Bio & NA & NA & NA & NA & NA \\
\hline $\mathrm{CO}$ & $0.002 \%$ & $0.002 \%$ & $0.000 \%$ & NA & $0.000 \%$ \\
\hline $\mathrm{CaO}$ & $0.016 \%$ & $0.016 \%$ & NA & $0.130 \%$ & NA \\
\hline $\mathrm{CdO}$ & $0.002 \%$ & $0.002 \%$ & NA & NA & NA \\
\hline $\mathrm{Cr}_{2} \mathrm{O}_{3}$ & $0.023 \%$ & $0.023 \%$ & $\mathrm{NA}$ & NA & NA \\
\hline $\mathrm{CuO}$ & $0.010 \%$ & $0.010 \%$ & NA & NA & NA \\
\hline $\mathrm{Fe}_{2} \mathrm{O}_{3}$ & $0.440 \%$ & $0.440 \%$ & $0.004 \%$ & $0.100 \%$ & NA \\
\hline $\mathrm{MgO}$ & $0.005 \%$ & $0.005 \%$ & NA & NA & NA \\
\hline $\mathrm{MnO}$ & $0.009 \%$ & $0.009 \%$ & NA & NA & NA \\
\hline $\mathrm{Na}_{2} \mathrm{O}$ & $0.002 \%$ & $0.002 \%$ & NA & NA & NA \\
\hline $\mathrm{NiO}$ & $0.005 \%$ & $0.005 \%$ & NA & NA & NA \\
\hline $\mathrm{PO}_{3}$ & $0.002 \%$ & $0.002 \%$ & $N A$ & NA & NA \\
\hline $\mathrm{PbO}$ & $0.166 \%$ & $0.166 \%$ & NA & NA & NA \\
\hline $\mathrm{Pu}$ & $0.258 \%$ & $0.258 \%$ & $0.372 \%$ & $0.262 \%$ & $0.340 \%$ \\
\hline $\mathrm{Se}$ & NA & NA & NA & NA & $N A$ \\
\hline $\mathrm{SiO}_{2}$ & $7.90 \%$ & $7.90 \%$ & $17.91 \%$ & NA & NA \\
\hline $\mathrm{Sm}_{2} \mathrm{O}_{3}$ & NA & NA & NA & NA & NA \\
\hline $\mathrm{Sr}$ & $0.000 \%$ & $0.000 \%$ & $0.000 \%$ & $0.000 \%$ & $0.000 \%$ \\
\hline $\mathrm{Tl}_{2} \mathrm{O}_{3}$ & NA & NA & $\mathrm{NA}$ & NA & NA \\
\hline Uo & $89.14 \%$ & $89.14 \%$ & $81.66 \%$ & $98.259 \%$ & $99.49 \%$ \\
\hline $\mathrm{ZnO}$ & $0.004 \%$ & $0.004 \%$ & NA & NA & $N A$ \\
\hline $\mathrm{ZrO}_{2}$ & $0.002 \%$ & $0.002 \%$ & NA & NA & $0.168 \%$ \\
\hline PCB & $0.036 \%$ & $0.036 \%$ & NA & NA & NA \\
\hline
\end{tabular}

Note: The Am and Pu numbers use the ERPG-2 for uranium. 
Table B-8. CWRG for the ERPG-3 Guideline -- KE Basin Canister and Fuel Wash Sludge

\begin{tabular}{|c|c|c|c|c|c|}
\hline \multirow[b]{2}{*}{ Analyte } & \multicolumn{2}{|c|}{ Canister Sludge } & \multicolumn{3}{|c|}{ Fuel Washing Sludge } \\
\hline & $\mathrm{Fu} 11$ & Empty & Internal & Coating & Pieces \\
\hline \multicolumn{6}{|c|}{ Mass Fractions Divided by the ERPG-3 Guidel ine $\left(\mathrm{m}^{3} / \mathrm{g}\right)$} \\
\hline $\mathrm{Ag}_{2} \mathrm{O}$ & 0.011 & 0.011 & NA & NA & NA \\
\hline $\mathrm{Al}_{2} \mathrm{O}_{3}$ & 7.693 & 7.693 & 0.438 & 8.824 & NA \\
\hline $\mathrm{Am}$ & 0.012 & 0.012 & 0.0032 & 0.0002 & 0.0007 \\
\hline $\mathrm{B}_{2} \mathrm{O}_{3}$ & 0.004 & 0.004 & NA & NA & NA \\
\hline $\mathrm{BaO}$ & 0.015 & 0.015 & NA & NA & NA \\
\hline $\mathrm{BeO}$ & 2.240 & 2.240 & NA & NA & NA \\
\hline $\mathrm{BiO}$ & NA & NA & NA & NA & NA \\
\hline $\mathrm{CO}$ & 0.020 & 0.020 & 0.006 & NA & 0.0013 \\
\hline $\mathrm{CaO}$ & 0.073 & 0.073 & NA & 0.614 & NA \\
\hline $\mathrm{CdO}$ & 0.011 & 0.011 & NA & NA & NA \\
\hline $\mathrm{Cr}_{2} \mathrm{O}_{3}$ & 0.026 & 0.026 & NA & NA & NA \\
\hline $\mathrm{CuO}$ & 0.005 & 0.005 & NA & NA & NA \\
\hline $\mathrm{Fe}_{2} \mathrm{O}_{3}$ & 0.049 & 0.049 & 0.0007 & 0.012 & NA \\
\hline $\mathrm{MgO}$ & 0.011 & 0.011 & NA & NA & NA \\
\hline MnO & 0.001 & 0.001 & NA & NA & NA \\
\hline $\mathrm{Na}_{2} \mathrm{O}$ & 0.004 & 0.004 & NA & NA & NA \\
\hline $\mathrm{NiO}$ & 0.014 & 0.014 & NA & NA & NA \\
\hline $\mathrm{PO}_{3}$ & 0.005 & 0.005 & $\mathrm{NA}$ & NA & NA \\
\hline $\mathrm{Pb0}$ & 0.005 & 0.005 & NA & NA & NA \\
\hline $\mathrm{Pu}$ & 0.174 & 0.174 & 0.374 & 0.185 & 0.316 \\
\hline $\mathrm{Se}$ & NA & NA & NA & NA & NA \\
\hline $\mathrm{SiO}_{2}$ & 1.776 & 1.776 & 6.011 & NA & NA \\
\hline $\mathrm{Sm}_{2} \mathrm{O}_{3}$ & NA & NA & NA & NA & NA \\
\hline $\mathrm{Sr}$ & 0.0000 & 0.0000 & 0.0000 & 0.0000 & 0.0000 \\
\hline $\mathrm{Tl}_{2} \mathrm{O}_{3}$ & NA & NA & NA & NA & NA \\
\hline UO & 60.13 & 60.13 & 82.21 & 69.47 & 92.56 \\
\hline Zno & 0.0013 & 0.0013 & $\mathrm{NA}$ & NA & NA \\
\hline $\mathrm{ZrO}_{2}$ & 0.011 & 0.011 & NA & NA & 1.305 \\
\hline PCB & 0.0000 & 0.0000 & NA & NA & NA \\
\hline Total CWRG: & 72.3 & 72.3 & 89.0 & 79.1 & 94.2 \\
\hline $1 / \mathrm{CWRG}, \mathrm{mg} / \mathrm{m}^{3}:$ & 13.8 & 13.8 & 11.2 & 12.6 & 10.6 \\
\hline
\end{tabular}


Table B-8. CWRG for the ERPG-3 Guideline -- KE Basin Canister and Fuel Wash Sludge

\begin{tabular}{|c|c|c|c|c|c|}
\hline \multirow[b]{2}{*}{ Analyte } & \multicolumn{2}{|c|}{ Canister Sludge } & \multicolumn{3}{|c|}{ Fuel Washing Sludge } \\
\hline & Fu11 & Empty & Internal & Coating & Pieces \\
\hline \multicolumn{6}{|c|}{ Percent Contributions to the CWRG for the ERPG-3 Guidel ine } \\
\hline $\mathrm{Ag}_{2} \mathrm{O}$ & $0.015 \%$ & $0.015 \%$ & NA & NA & NA \\
\hline $\mathrm{Al}_{2} \mathrm{O}_{3}$ & $10.64 \%$ & $10.64 \%$ & $0.492 \%$ & $11.16 \%$ & NA \\
\hline $\mathrm{Am}$ & $0.017 \%$ & $0.017 \%$ & $0.004 \%$ & $0.000 \%$ & $0.001 \%$ \\
\hline $\mathrm{B}_{2} \mathrm{O}_{3}$ & $0.006 \%$ & $0.006 \%$ & NA & NA & NA \\
\hline $\mathrm{BaO}$ & $0.020 \%$ & $0.020 \%$ & NA & NA & NA \\
\hline $\mathrm{Be0}$ & $3.098 \%$ & $3.098 \%$ & NA & NA & NA \\
\hline $\mathrm{BiO}$ & NA & $N A$ & NA & NA & $\mathrm{NA}$ \\
\hline $\mathrm{CO}$ & $0.027 \%$ & $0.027 \%$ & $0.006 \%$ & NA & $0.001 \%$ \\
\hline $\mathrm{CaO}$ & $0.102 \%$ & $0.102 \%$ & NA & $0.777 \%$ & NA \\
\hline $\mathrm{CdO}$ & $0.015 \%$ & $0.015 \%$ & NA & NA & NA \\
\hline $\mathrm{Cr}_{2} \mathrm{O}_{3}$ & $0.036 \%$ & $0.036 \%$ & NA & NA & NA \\
\hline CuO & $0.008 \%$ & $0.008 \%$ & NA & NA & NA \\
\hline $\mathrm{Fe}_{2} \mathrm{O}_{3}$ & $0.068 \%$ & $0.068 \%$ & $0.001 \%$ & $0.015 \%$ & NA \\
\hline $\mathrm{MgO}$ & $0.015 \%$ & $0.015 \%$ & NA & NA & NA \\
\hline $\mathrm{MnO}$ & $0.001 \%$ & $0.001 \%$ & $\mathrm{NA}$ & $\mathrm{NA}$ & NA \\
\hline $\mathrm{Na}_{2} \mathrm{O}$ & $0.005 \%$ & $0.005 \%$ & NA & NA & NA \\
\hline $\mathrm{NiO}$ & $0.020 \%$ & $0.020 \%$ & NA & NA & $\mathrm{NA}$ \\
\hline $\mathrm{PO}_{3}$ & $0.006 \%$ & $0.006 \%$ & NA & NA & NA \\
\hline $\mathrm{PbO}$ & $0.006 \%$ & $0.006 \%$ & NA & NA & NA \\
\hline $\mathrm{Pu}$ & $0.240 \%$ & $0.240 \%$ & $0.420 \%$ & $0.234 \%$ & $0.336 \%$ \\
\hline $\mathrm{Se}$ & NA & NA & NA & NA & NA \\
\hline $\mathrm{SiO}_{2}$ & $2.46 \%$ & $2.46 \%$ & $6.75 \%$ & NA & $N A$ \\
\hline $\mathrm{Sm}_{2} \mathrm{O}_{3}$ & NA & NA & NA & $\mathrm{NA}$ & NA \\
\hline $\mathrm{Sr}$ & $0.000 \%$ & $0.000 \%$ & $0.000 \%$ & $0.000 \%$ & $0.000 \%$ \\
\hline $\mathrm{Tl}_{2} \mathrm{O}_{3}$ & NA & NA & NA & NA & NA \\
\hline UO & $83.18 \%$ & $83.18 \%$ & $92.33 \%$ & $87.82 \%$ & $98.28 \%$ \\
\hline $\mathrm{ZnO}$ & $0.002 \%$ & $0.002 \%$ & $\mathrm{NA}$ & NA & NA \\
\hline $\mathrm{ZrO}_{2}$ & $0.016 \%$ & $0.016 \%$ & $\mathrm{NA}$ & NA & $1.385 \%$ \\
\hline PCB & $0.000 \%$ & $0.000 \%$ & NA & NA & NA \\
\hline
\end{tabular}

Note: The Am and Pu numbers use the ERPG-3 for uranium. 
Table B-9. CWRG for the PEL-TWA Guideline -- KW Basin Canister and Fuel Wash Sludge

\begin{tabular}{|c|c|c|c|c|c|}
\hline \multirow[b]{2}{*}{ Analyte } & \multicolumn{2}{|c|}{ Canister Sludge } & \multicolumn{3}{|c|}{ Fuel Washing Sludge } \\
\hline & Full & Empty & Internal & Coating & Pieces \\
\hline \multicolumn{6}{|c|}{ Mass Fractions Divided by the PEL-TWA Guideline $\left(\mathrm{m}^{3} / \mathrm{g}\right)$} \\
\hline $\mathrm{Ag}_{2} \mathrm{O}$ & NA & NA & NA & NA & NA \\
\hline $\mathrm{Al}_{2} \mathrm{O}_{3}$ & 6.202 & 6.20 & 5.760 & 57.68 & NA \\
\hline $\mathrm{Am}$ & 0.871 & 0.871 & 0.461 & 0.011 & 0.144 \\
\hline $\mathrm{B}_{2} \mathrm{O}_{3}$ & NA & NA & NA & NA & NA \\
\hline $\mathrm{BaO}$ & 0.596 & 0.596 & NA & NA & $N A$ \\
\hline $\mathrm{Be} 0$ & 72.21 & 72.21 & NA & NA & NA \\
\hline Bio & NA & NA & NA & NA & NA \\
\hline $\mathrm{CO}$ & 0.077 & 0.077 & NA & NA & NA \\
\hline $\mathrm{CaO}$ & NA & NA & NA & 0.970 & NA \\
\hline $\mathrm{CdO}$ & NA & NA & NA & NA & NA \\
\hline $\mathrm{Cr}_{2} \mathrm{O}_{3}$ & 0.986 & 0.986 & NA & NA & NA \\
\hline $\mathrm{CuO}$ & NA & NA & NA & NA & NA \\
\hline $\mathrm{Fe}_{2} \mathrm{O}_{3}$ & 11.02 & 11.02 & 0.180 & 32.52 & NA \\
\hline $\mathrm{MgO}$ & NA & NA & NA & NA & NA \\
\hline MnO & 1.932 & 1.932 & NA & NA & NA \\
\hline $\mathrm{Na}_{2} \mathrm{O}$ & NA & NA & NA & NA & NA \\
\hline $\mathrm{NiO}$ & 0.347 & 0.347 & NA & NA & NA \\
\hline $\mathrm{PO}_{3}$ & NA & NA & NA & NA & NA \\
\hline $\mathrm{Pb0}$ & NA & NA & NA & NA & NA \\
\hline $\mathrm{Pu}$ & 59.54 & 59.54 & 61.27 & 1.55 & 65.59 \\
\hline $\mathrm{Se}$ & NA & NA & NA & NA & NA \\
\hline $\mathrm{SiO}_{2}$ & NA & NA & 866.4 & 305.6 & NA \\
\hline $\mathrm{Sm}_{2} \mathrm{O}_{3}$ & NA & NA & $\mathrm{NA}$ & NA & NA \\
\hline Sr & 0.002 & 0.002 & 0.001 & 0.000 & 0.001 \\
\hline $\mathrm{Tl}_{2} \mathrm{O}_{3}$ & NA & NA & NA & NA & NA \\
\hline UO & 15,789 & 15,789 & 16,857 & 470.5 & 18,523 \\
\hline $\mathrm{ZnO}$ & 0.081 & 0.081 & NA & NA & NA \\
\hline $\mathrm{ZrO}_{2}$ & 0.125 & 0.125 & NA & NA & 13.05 \\
\hline $\mathrm{PCB}$ & 7.907 & 7.907 & NA & $\mathrm{NA}$ & NA \\
\hline Total CWRG: & 15,951 & 15,951 & 17,792 & 869 & 18,602 \\
\hline $1 / \mathrm{CWRG}, \mathrm{mg} / \mathrm{m}^{3}:$ & 0.063 & 0.063 & 0.056 & 1,151 & 0.054 \\
\hline
\end{tabular}


Table B-9. CWRG for the PEL-TWA Guideline -- KW Basin Canister and Fuel Wash s7udge

\begin{tabular}{|c|c|c|c|c|c|}
\hline \multirow[b]{2}{*}{ Analyte } & \multicolumn{2}{|c|}{ Canister Sludge } & \multicolumn{3}{|c|}{ Fuel Washing Sludge } \\
\hline & Ful1 & Empty & Internal & Coating & Pieces \\
\hline \multicolumn{6}{|c|}{ Percent Contributions to the CWRG for the PEL-TWA Guideline } \\
\hline $\mathrm{Ag}_{2} \mathrm{O}$ & NA & $\mathrm{NA}$ & NA & NA & NA \\
\hline $\mathrm{Al}_{2} \mathrm{O}_{3}$ & $0.039 \%$ & $0.039 \%$ & $0.032 \%$ & $6.638 \%$ & NA \\
\hline Am & $0.005 \%$ & $0.005 \%$ & $0.003 \%$ & $0.001 \%$ & $0.001 \%$ \\
\hline $\mathrm{B}_{2} \mathrm{O}_{3}$ & NA & NA & NA & NA & NA \\
\hline $\mathrm{BaO}$ & $0.004 \%$ & $0.004 \%$ & NA & NA & NA \\
\hline $\mathrm{BeO}$ & $0.453 \%$ & $0.453 \%$ & NA & NA & NA \\
\hline $\mathrm{BiO}$ & NA & NA & NA & NA & NA \\
\hline $\mathrm{CO}$ & $0.000 \%$ & $0.000 \%$ & NA & NA & NA \\
\hline $\mathrm{CaO}$ & NA & NA & NA & $0.112 \%$ & NA \\
\hline cdo & NA & NA & $N A$ & NA & $N A$ \\
\hline $\mathrm{Cr}_{2} \mathrm{O}_{3}$ & $0.006 \%$ & $0.006 \%$ & NA & NA & NA \\
\hline $\mathrm{CuO}$ & NA & NA & NA & NA & NA \\
\hline $\mathrm{Fe}_{2} \mathrm{O}_{3}$ & $0.069 \%$ & $0.069 \%$ & $0.001 \%$ & $3.743 \%$ & NA \\
\hline $\mathrm{MgO}$ & NA & NA & NA & NA & $N A$ \\
\hline Mno & $0.012 \%$ & $0.012 \%$ & NA & NA & NA \\
\hline $\mathrm{Na}_{2} \mathrm{O}$ & NA & NA & NA & NA & NA \\
\hline $\mathrm{NiO}$ & $0.002 \%$ & $0.002 \%$ & NA & NA & $N A$ \\
\hline $\mathrm{PO}_{3}$ & NA & NA & NA & NA & NA \\
\hline $\mathrm{PbO}$ & NA & NA & NA & NA & NA \\
\hline $\mathrm{Pu}$ & $0.373 \%$ & $0.373 \%$ & $0.344 \%$ & $0.178 \%$ & $0.353 \%$ \\
\hline $\mathrm{Se}$ & $N A$ & $N A$ & NA & NA & NA \\
\hline $\mathrm{SiO}_{2}$ & NA & NA & $4.87 \%$ & $35.18 \%$ & NA \\
\hline $\mathrm{Sm}_{2} \mathrm{O}_{3}$ & NA & NA & NA & NA & NA \\
\hline $\mathrm{Sr}$ & $0.000 \%$ & $0.000 \%$ & $0.000 \%$ & $0.000 \%$ & $0.000 \%$ \\
\hline $\mathrm{Tl}_{2} \mathrm{O}_{3}$ & NA & NA & $\mathrm{NA}$ & NA & NA \\
\hline UO & $98.98 \%$ & $98.98 \%$ & $94.75 \%$ & $54.15 \%$ & $99.58 \%$ \\
\hline Zno & $0.001 \%$ & $0.001 \%$ & NA & NA & NA \\
\hline $\mathrm{ZrO}_{2}$ & $0.001 \%$ & $0.001 \%$ & $N A$ & NA & $0.070 \%$ \\
\hline $\mathrm{PCB}$ & $0.050 \%$ & $0.050 \%$ & NA & NA & NA \\
\hline
\end{tabular}

Note: The Am and $\mathrm{Pu}$ numbers use the PEL-TWA for uranium. 
Table B-10. CWRG for the ERPG-1 Guideline -- KW Basin Canister and Fuel Wash Sludge

\begin{tabular}{|c|c|c|c|c|c|}
\hline \multirow[b]{2}{*}{ Analyte } & \multicolumn{2}{|c|}{ Canister Sludge } & \multicolumn{3}{|c|}{ Fuel Washing Sludge } \\
\hline & Ful1 & Empty & Internal & Coating & Pieces \\
\hline \multicolumn{6}{|c|}{ Mass Fractions Divided by the ERPG-1 Guidel ine $\left(\mathrm{m}^{3} / \mathrm{g}\right)$} \\
\hline $\mathrm{Ag}_{2} \mathrm{O}$ & NA & NA & NA & NA & NA \\
\hline $\mathrm{Al}_{2} \mathrm{O}_{3}$ & 4.13 & 4.13 & 3.840 & 38.45 & NA \\
\hline $\mathrm{Am}$ & 0.073 & 0.073 & 0.038 & 0.001 & 0.012 \\
\hline $\mathrm{B}_{2} \mathrm{O}_{3}$ & NA & NA & NA & NA & NA \\
\hline $\mathrm{BaO}$ & 0.199 & 0.199 & NA & NA & NA \\
\hline $\mathrm{BeO}$ & 14.44 & 14.44 & NA & NA & NA \\
\hline $\mathrm{BiO}$ & NA & NA & NA & NA & NA \\
\hline $\mathrm{CO}$ & 0.014 & 0.014 & NA & NA & NA \\
\hline $\mathrm{CaO}$ & NA & NA & NA & 0.808 & NA \\
\hline $\mathrm{CdO}$ & NA & NA & NA & NA & NA \\
\hline $\mathrm{Cr}_{2} \mathrm{O}_{3}$ & 0.329 & 0.329 & NA & NA & NA \\
\hline $\mathrm{CuO}$ & NA & NA & $N A$ & NA & $N A$ \\
\hline $\mathrm{Fe}_{2} \mathrm{O}_{3}$ & 7.346 & 7.346 & 0.120 & 21.681 & NA \\
\hline $\mathrm{MgO}$ & NA & NA & NA & NA & NA \\
\hline $\mathrm{MnO}$ & 0.129 & 0.129 & NA & NA & NA \\
\hline $\mathrm{Na}_{2} \mathrm{O}$ & NA & NA & NA & NA & $N A$ \\
\hline $\mathrm{NiO}$ & 0.116 & 0.116 & NA & NA & NA \\
\hline $\mathrm{PO}_{3}$ & NA & NA & NA & NA & NA \\
\hline $\mathrm{PbO}$ & $N A$ & NA & NA & NA & NA \\
\hline $\mathrm{Pu}$ & 4.962 & 4.962 & 5.106 & 0.129 & 5.466 \\
\hline $\mathrm{Se}$ & NA & NA & NA & NA & NA \\
\hline $\mathrm{SiO}_{2}$ & NA & NA & 288.8 & 102 & NA \\
\hline $\mathrm{Sm}_{2} \mathrm{O}_{3}$ & NA & NA & NA & NA & NA \\
\hline $\mathrm{Sr}$ & 0.001 & 0.001 & 0.000 & 0.000 & 0.000 \\
\hline $\mathrm{Tl}_{2} \mathrm{O}_{3}$ & NA & NA & NA & NA & NA \\
\hline $\mathrm{U0}$ & 1,316 & 1,316 & 1,405 & 39 & 1,544 \\
\hline Zno & 0.054 & 0.054 & $N A$ & NA & NA \\
\hline $\mathrm{ZrO}_{2}$ & 0.063 & 0.063 & NA & NA & 6.527 \\
\hline $\mathrm{PCB}$ & 2.636 & 2.636 & NA & NA & NA \\
\hline Total CWRG: & 1,350 & 1,350 & 1,703 & 202 & 1,556 \\
\hline $1 /$ CWRG, $\mathrm{mg} / \mathrm{m}^{3}:$ & 0.741 & 0.741 & 0.587 & 4.947 & 0.643 \\
\hline
\end{tabular}


Table B-10. CWRG for the ERPG-1 Guideline -- KW Basin Canister and Fuel Wash STudge

\begin{tabular}{|c|c|c|c|c|c|}
\hline \multirow[b]{2}{*}{ Analyte } & \multicolumn{2}{|c|}{ Canister Sludge } & \multicolumn{3}{|c|}{ Fuel Washing Sludge } \\
\hline & FuTl & Empty & Internal & Coating & Pieces \\
\hline \multicolumn{6}{|c|}{ Percent Contributions to the CWRG for the ERPG-1 Guideline } \\
\hline $\mathrm{Ag}_{2} \mathrm{O}$ & NA & NA & NA & NA & NA \\
\hline $\mathrm{Al}_{2} \mathrm{O}_{3}$ & $0.306 \%$ & $0.306 \%$ & $0.226 \%$ & $19.021 \%$ & NA \\
\hline Am & $0.005 \%$ & $0.005 \%$ & $0.002 \%$ & $0.000 \%$ & $0.001 \%$ \\
\hline $\mathrm{B}_{2} \mathrm{O}_{3}$ & NA & NA & $N A$ & NA & NA \\
\hline $\mathrm{BaO}$ & $0.015 \%$ & $0.015 \%$ & NA & NA & NA \\
\hline $\mathrm{BeO}$ & $1.070 \%$ & $1.070 \%$ & NA & NA & NA \\
\hline $\mathrm{BiO}$ & NA & NA & NA & NA & NA \\
\hline $\mathrm{CO}$ & $0.001 \%$ & $0.001 \%$ & NA & NA & $\mathrm{NA}$ \\
\hline $\mathrm{CaO}$ & NA & $N A$ & NA & $0.400 \%$ & NA \\
\hline $\mathrm{CdO}$ & NA & NA & NA & NA & NA \\
\hline $\mathrm{Cr}_{2} \mathrm{O}_{3}$ & $0.024 \%$ & $0.024 \%$ & NA & NA & NA \\
\hline CuO & NA & NA & NA & NA & NA \\
\hline $\mathrm{Fe}_{2} \mathrm{O}_{3}$ & $0.544 \%$ & $0.544 \%$ & $0.007 \%$ & $10.725 \%$ & NA \\
\hline $\mathrm{MgO}$ & NA & NA & $N A$ & NA & NA \\
\hline $\mathrm{MnO}$ & $0.010 \%$ & $0.010 \%$ & NA & NA & $\mathrm{NA}$ \\
\hline $\mathrm{Na}_{2} \mathrm{O}$ & NA & NA & NA & NA & NA \\
\hline $\mathrm{NiO}$ & $0.009 \%$ & $0.009 \%$ & NA & NA & $\mathrm{NA}$ \\
\hline $\mathrm{PO}_{3}$ & $N A$ & $\mathrm{NA}$ & NA & NA & NA \\
\hline $\mathrm{Pb0}$ & $\mathrm{NA}$ & NA & NA & NA & NA \\
\hline $\mathrm{Pu}$ & $0.367 \%$ & $0.367 \%$ & $0.300 \%$ & $0.064 \%$ & $0.351 \%$ \\
\hline $\mathrm{Se}$ & NA & NA & NA & NA & NA \\
\hline $\mathrm{SiO}_{2}$ & NA & NA & $16.96 \%$ & $50.40 \%$ & $\mathrm{NA}$ \\
\hline $\mathrm{Sm}_{2} \mathrm{O}_{3}$ & NA & NA & NA & NA & NA \\
\hline $\mathrm{Sr}$ & $0.000 \%$ & $0.000 \%$ & $0.000 \%$ & $0.000 \%$ & $0.000 \%$ \\
\hline $\mathrm{Tl}_{2} \mathrm{O}_{3}$ & NA & NA & NA & NA & NA \\
\hline U0 & $97.45 \%$ & $97.45 \%$ & $82.50 \%$ & $19.39 \%$ & $99.23 \%$ \\
\hline $\mathrm{ZnO}$ & $0.004 \%$ & $0.004 \%$ & NA & NA & NA \\
\hline $\mathrm{ZrO}_{2}$ & $0.005 \%$ & $0.005 \%$ & NA & NA & $0.420 \%$ \\
\hline PCB & $0.195 \%$ & $0.195 \%$ & NA & NA & NA \\
\hline
\end{tabular}

Note: The $A m$ and $\mathrm{Pu}$ numbers use the ERPG-1 for uranium. 
Table B-11. CWRG for the ERPG-2 Guideline -- KW Basin Canister and Fuel Wash Sludge

\begin{tabular}{|c|c|c|c|c|c|}
\hline \multirow[b]{2}{*}{ Analyte } & \multicolumn{2}{|c|}{ Canister Sludge } & \multicolumn{3}{|c|}{ Fuel Washing Sludge } \\
\hline & Fu11 & Empty & Internal & Coating & Pieces \\
\hline \multicolumn{6}{|c|}{ Mass Fractions Divided by the ERPG-2 Guidel ine $\left(\mathrm{m}^{3} / \mathrm{g}\right)$} \\
\hline $\mathrm{Ag}_{2} \mathrm{O}$ & $\mathrm{NA}$ & NA & NA & NA & NA \\
\hline $\mathrm{Al}_{2} \mathrm{O}_{3}$ & 4.13 & 4.13 & 3.840 & 38.45 & NA \\
\hline $\mathrm{Am}$ & 0.073 & 0.073 & 0.038 & 0.001 & 0.012 \\
\hline $\mathrm{B}_{2} \mathrm{O}_{3}$ & NA & NA & NA & NA & NA \\
\hline $\mathrm{BaO}$ & 0.119 & 0.119 & NA & NA & NA \\
\hline $\mathrm{BeO}$ & 5.777 & 5.777 & NA & NA & NA \\
\hline $\mathrm{BiO}$ & NA & NA & NA & NA & NA \\
\hline $\mathrm{CO}$ & 0.008 & 0.008 & NA & NA & NA \\
\hline $\mathrm{CaO}$ & $\mathrm{NA}$ & NA & NA & 0.485 & NA \\
\hline $\mathrm{CdO}$ & NA & NA & NA & NA & NA \\
\hline $\mathrm{Cr}_{2} \mathrm{O}_{3}$ & 0.197 & 0.197 & NA & NA & NA \\
\hline CuO & NA & NA & NA & NA & NA \\
\hline $\mathrm{Fe}_{2} \mathrm{O}_{3}$ & 4.408 & 4.408 & 0.072 & 13.009 & NA \\
\hline $\mathrm{MgO}$ & NA & NA & NA & NA & NA \\
\hline $\mathrm{MnO}$ & 0.077 & 0.077 & NA & NA & NA \\
\hline $\mathrm{Na}_{2} \mathrm{O}$ & NA & NA & NA & NA & NA \\
\hline $\mathrm{NiO}$ & 0.069 & 0.069 & NA & NA & NA \\
\hline $\mathrm{PO}_{3}$ & NA & NA & NA & NA & NA \\
\hline Pbo & NA & NA & NA & NA & NA \\
\hline $\mathrm{Pu}$ & 4.962 & 4.962 & 5.106 & 0.129 & 5.466 \\
\hline $\mathrm{Se}$ & NA & NA & NA & NA & NA \\
\hline $\mathrm{SiO}_{2}$ & NA & NA & 173.3 & 61 & NA \\
\hline $\mathrm{Sm}_{2} \mathrm{O}_{3}$ & NA & NA & NA & NA & NA \\
\hline $\mathrm{Sr}$ & 0.000 & 0.000 & 0.000 & 0.000 & 0.000 \\
\hline $\mathrm{Tl}_{2} \mathrm{O}_{3}$ & NA & NA & $\mathrm{NA}$ & NA & NA \\
\hline U0 & 1,316 & 1,316 & 1,405 & 39 & 1,544 \\
\hline Zno & 0.054 & 0.054 & NA & NA & NA \\
\hline $\mathrm{ZrO}_{2}$ & 0.025 & 0.025 & NA & NA & 2.611 \\
\hline PCB & 1.581 & 1.581 & NA & NA & NA \\
\hline Total CWRG: & 1,337 & 1,337 & 1,587 & 152 & 1,552 \\
\hline $1 / \mathrm{CWRG}, \mathrm{mg} / \mathrm{m}^{3}:$ & 0.748 & 0.748 & 0.630 & 6.561 & 0.644 \\
\hline
\end{tabular}


Table B-11. CWRG for the ERPG-2 Guideline -- KW Basin Canister and Fuel Wash Sludge

\begin{tabular}{|c|c|c|c|c|c|}
\hline \multirow[b]{2}{*}{ Analyte } & \multicolumn{2}{|c|}{ Canister Sludge } & \multicolumn{3}{|c|}{ Fuel Washing Sludge } \\
\hline & Ful1 & Empty & Interna1 & Coating & Pieces \\
\hline \multicolumn{6}{|c|}{ Percent Contributions to the CWRG for the ERPG-2 Guideline } \\
\hline $\mathrm{Ag}_{2} \mathrm{O}$ & NA & NA & NA & NA & NA \\
\hline $\mathrm{Al}_{2} \mathrm{O}_{3}$ & $0.309 \%$ & $0.309 \%$ & $0.242 \%$ & $25.229 \%$ & NA \\
\hline Am & $0.005 \%$ & $0.005 \%$ & $0.002 \%$ & $0.001 \%$ & $0.001 \%$ \\
\hline $\mathrm{B}_{2} \mathrm{O}_{3}$ & NA & NA & $N A$ & NA & NA \\
\hline $\mathrm{BaO}$ & $0.009 \%$ & $0.009 \%$ & NA & $N A$ & NA \\
\hline $\mathrm{BeO}$ & $0.432 \%$ & $0.432 \%$ & NA & NA & NA \\
\hline $\mathrm{BiO}$ & NA & NA & NA & NA & NA \\
\hline $\mathrm{CO}$ & $0.001 \%$ & $0.001 \%$ & NA & NA & NA \\
\hline $\mathrm{CaO}$ & NA & NA & NA & $0.318 \%$ & NA \\
\hline $\mathrm{CdO}$ & $\mathrm{NA}$ & NA & NA & NA & $\mathrm{NA}$ \\
\hline $\mathrm{Cr}_{2} \mathrm{O}_{3}$ & $0.015 \%$ & $0.015 \%$ & NA & NA & NA \\
\hline $\mathrm{CuO}$ & $\mathrm{NA}$ & NA & $\mathrm{NA}$ & $\mathrm{NA}$ & $\mathrm{NA}$ \\
\hline $\mathrm{Fe}_{2} \mathrm{O}_{3}$ & $0.330 \%$ & $0.330 \%$ & $0.005 \%$ & $8.536 \%$ & $\mathrm{NA}$ \\
\hline $\mathrm{MgO}$ & NA & NA & NA & NA & NA \\
\hline $\mathrm{MnO}$ & $0.006 \%$ & $0.006 \%$ & NA & NA & NA \\
\hline $\mathrm{Na}_{2} \mathrm{O}$ & NA & NA & NA & NA & NA \\
\hline $\mathrm{NiO}$ & $0.005 \%$ & $0.005 \%$ & $\mathrm{NA}$ & NA & NA \\
\hline $\mathrm{PO}_{3}$ & $\mathrm{NA}$ & NA & NA & NA & $\mathrm{NA}$ \\
\hline $\mathrm{Pb0}$ & $\mathrm{NA}$ & NA & NA & NA & $\mathrm{NA}$ \\
\hline $\mathrm{Pu}$ & $0.371 \%$ & $0.371 \%$ & $0.322 \%$ & $0.085 \%$ & $0.352 \%$ \\
\hline Se & NA & NA & NA & NA & NA \\
\hline $\mathrm{SiO}_{2}$ & NA & $\mathrm{NA}$ & $10.92 \%$ & $40.11 \%$ & $\mathrm{NA}$ \\
\hline $\mathrm{Sm}_{2} \mathrm{O}_{3}$ & NA & NA & NA & NA & NA \\
\hline $\mathrm{Sr}$ & $0.000 \%$ & $0.000 \%$ & $0.000 \%$ & $0.000 \%$ & $0.000 \%$ \\
\hline $\mathrm{Tl}_{2} \mathrm{O}_{3}$ & NA & NA & NA & NA & NA \\
\hline vo & $98.39 \%$ & $98.39 \%$ & $88.51 \%$ & $25.725 \%$ & $99.48 \%$ \\
\hline Zno & $0.004 \%$ & $0.004 \%$ & $N A$ & NA & NA \\
\hline $\mathrm{ZrO}_{2}$ & $0.002 \%$ & $0.002 \%$ & NA & NA & $0.168 \%$ \\
\hline PCB & $0.118 \%$ & $0.118 \%$ & NA & NA & NA \\
\hline
\end{tabular}

Note: The $A m$ and $P u$ numbers use the ERPG-2 for uranium. 
Table B-12. CWRG for the ERPG-3 Guideline -- KW Basin Canister and Fuel Wash Sludge

\begin{tabular}{|c|c|c|c|c|c|}
\hline \multirow[b]{2}{*}{ Analyte } & \multicolumn{2}{|c|}{ Canister Sludge } & \multicolumn{3}{|c|}{ Fuel Washing Sludge } \\
\hline & Fu11 & Empty & Internal & Coating & Pieces \\
\hline \multicolumn{6}{|c|}{ Mass Fractions Divided by the ERPG-3 Guidel ine $\left(\mathrm{m}^{3} / \mathrm{g}\right)$} \\
\hline $\mathrm{Ag}_{2} \mathrm{O}$ & NA & NA & NA & NA & NA \\
\hline $\mathrm{Al}_{2} \mathrm{O}_{3}$ & 2.481 & 2.481 & 2.304 & 23.070 & NA \\
\hline $\mathrm{Am}$ & 0.004 & 0.004 & 0.0023 & 0.0001 & 0.0007 \\
\hline $\mathrm{B}_{2} \mathrm{O}_{3}$ & NA & NA & NA & NA & NA \\
\hline $\mathrm{BaO}$ & 0.024 & 0.024 & NA & NA & NA \\
\hline $\mathrm{BeO}$ & 1.444 & 1.444 & NA & NA & NA \\
\hline $\mathrm{BiO}$ & NA & NA & NA & NA & NA \\
\hline $\mathrm{CO}$ & 0.005 & 0.005 & NA & NA & NA \\
\hline $\mathrm{CaO}$ & NA & NA & NA & 0.194 & NA \\
\hline $\mathrm{CdO}$ & NA & NA & NA & NA & NA \\
\hline $\mathrm{Cr}_{2} \mathrm{O}_{3}$ & 0.020 & 0.020 & NA & NA & NA \\
\hline CuO & NA & NA & NA & NA & NA \\
\hline $\mathrm{Fe}_{2} \mathrm{O}_{3}$ & 0.044 & 0.044 & 0.0007 & 0.130 & NA \\
\hline $\mathrm{MgO}$ & $N A$ & NA & NA & NA & NA \\
\hline MnO & 0.001 & 0.001 & NA & NA & NA \\
\hline $\mathrm{Na}_{2} \mathrm{O}$ & NA & NA & NA & NA & NA \\
\hline $\mathrm{NiO}$ & 0.017 & 0.017 & NA & NA & $\mathrm{NA}$ \\
\hline $\mathrm{PO}_{3}$ & NA & NA & NA & NA & NA \\
\hline $\mathrm{PbO}$ & NA & NA & NA & NA & NA \\
\hline $\mathrm{Pu}$ & 0.298 & 0.298 & 0.306 & 0.008 & 0.328 \\
\hline $\mathrm{Se}$ & NA & $N A$ & $N A$ & NA & NA \\
\hline $\mathrm{SiO}_{2}$ & $N A$ & NA & 3.466 & 1.223 & NA \\
\hline $\mathrm{Sm}_{2} \mathrm{O}_{3}$ & NA & NA & NA & NA & NA \\
\hline $\mathrm{Sr}$ & 0.0000 & 0.0000 & 0.0000 & 0.0000 & 0.0000 \\
\hline $\mathrm{Tl}_{2} \mathrm{O}_{3}$ & $N A$ & NA & NA & NA & NA \\
\hline UO & 78.94 & 78.94 & 84.29 & 2.35 & 92.61 \\
\hline $\mathrm{ZnO}$ & 0.0016 & 0.0016 & NA & NA & NA \\
\hline $\mathrm{ZrO}_{2}$ & 0.013 & 0.013 & NA & NA & 1.305 \\
\hline PCB & 0.0000 & 0.0000 & NA & $\mathrm{NA}$ & NA \\
\hline Total CWRG: & 83.3 & 83.3 & 90.4 & 27.0 & 94.2 \\
\hline $1 / \mathrm{CWRG}, \mathrm{mg} / \mathrm{m}^{3}:$ & 12.0 & 12.0 & 11.1 & 37.1 & 10.6 \\
\hline
\end{tabular}


Table B-12. CWRG for the ERPG-3 Guideline -- KW Basin Canister and Fuel Wash Sludge

\begin{tabular}{|c|c|c|c|c|c|}
\hline \multirow[b]{2}{*}{ Analyte } & \multicolumn{2}{|c|}{ Canister Sludge } & \multicolumn{3}{|c|}{ Fuel Washing Sludge } \\
\hline & Full & Empty & Internal & Coating & Pieces \\
\hline \multicolumn{6}{|c|}{ Percent Contributions to the CWRG for the ERPG-3 Guidel ine } \\
\hline $\mathrm{Ag}_{2} \mathrm{O}$ & NA & NA & NA & NA & NA \\
\hline $\mathrm{Al}_{2} \mathrm{O}_{3}$ & $2.98 \%$ & $2.98 \%$ & $2.550 \%$ & $85.52 \%$ & NA \\
\hline $\mathrm{Am}$ & $0.005 \%$ & $0.005 \%$ & $0.003 \%$ & $0.000 \%$ & $0.001 \%$ \\
\hline $\mathrm{B}_{2} \mathrm{O}_{3}$ & NA & $\mathrm{NA}$ & NA & NA & NA \\
\hline $\mathrm{BaO}$ & $0.029 \%$ & $0.029 \%$ & NA & NA & NA \\
\hline $\mathrm{BeO}$ & $1.734 \%$ & $1.734 \%$ & NA & NA & NA \\
\hline Bio & $N A$ & NA & NA & NA & NA \\
\hline $\mathrm{CO}$ & $0.006 \%$ & $0.006 \%$ & NA & NA & NA \\
\hline $\mathrm{CaO}$ & NA & NA & NA & $0.719 \%$ & NA \\
\hline $\mathrm{CdO}$ & NA & NA & NA & NA & NA \\
\hline $\mathrm{Cr}_{2} \mathrm{O}_{3}$ & $0.024 \%$ & $0.024 \%$ & NA & NA & NA \\
\hline $\mathrm{CuO}$ & NA & NA & NA & NA & NA \\
\hline $\mathrm{Fe}_{2} \mathrm{O}_{3}$ & $0.053 \%$ & $0.053 \%$ & $0.001 \%$ & $0.482 \%$ & NA \\
\hline $\mathrm{MgO}$ & NA & NA & NA & NA & NA \\
\hline MnO & $0.001 \%$ & $0.001 \%$ & NA & NA & NA \\
\hline $\mathrm{Na}_{2} \mathrm{O}$ & NA & $\mathrm{NA}$ & NA & NA & NA \\
\hline $\mathrm{NiO}$ & $0.021 \%$ & $0.021 \%$ & NA & NA & NA \\
\hline $\mathrm{PO}_{3}$ & NA & NA & NA & $N A$ & NA \\
\hline $\mathrm{PbO}$ & $N A$ & NA & NA & NA & NA \\
\hline $\mathrm{Pu}$ & $0.357 \%$ & $0.357 \%$ & $0.339 \%$ & $0.029 \%$ & $0.348 \%$ \\
\hline $\mathrm{Se}$ & NA & NA & $N A$ & NA & NA \\
\hline $\mathrm{SiO}_{2}$ & NA & $N A$ & $3.84 \%$ & $4.53 \%$ & NA \\
\hline $\mathrm{Sm}_{2} \mathrm{O}_{3}$ & NA & NA & NA & NA & NA \\
\hline $\mathrm{Sr}$ & $0.000 \%$ & $0.000 \%$ & $0.000 \%$ & $0.000 \%$ & $0.000 \%$ \\
\hline $\mathrm{Tl}_{2} \mathrm{O}_{3}$ & NA & NA & NA & NA & NA \\
\hline Uo & $94.77 \%$ & $94.77 \%$ & $93.27 \%$ & $8.72 \%$ & $98.27 \%$ \\
\hline $\mathrm{ZnO}$ & $0.002 \%$ & $0.002 \%$ & NA & NA & NA \\
\hline $\mathrm{ZrO}_{2}$ & $0.015 \%$ & $0.015 \%$ & NA & NA & $1.385 \%$ \\
\hline PCB & $0.000 \%$ & $0.000 \%$ & NA & NA & NA \\
\hline
\end{tabular}

Note: The Am and Pu numbers use the ERPG-3 for uranium. 
DISTRIBUTION SHEET

\begin{tabular}{|c|c|c|c|c|c|}
\hline \multirow{2}{*}{$\begin{array}{l}\text { To } \\
\text { Distribution }\end{array}$} & \multirow{2}{*}{\multicolumn{3}{|c|}{$\begin{array}{l}\text { From } \\
\text { Nuclear Safety }\end{array}$}} & \multicolumn{2}{|l|}{ Page 1 of 1} \\
\hline & & & & \multicolumn{2}{|c|}{ Date $9-29-99$} \\
\hline \multicolumn{4}{|l|}{ Project Title/Work Order } & \multicolumn{2}{|c|}{ EDT №. 626895} \\
\hline \multirow{2}{*}{\multicolumn{4}{|c|}{$\begin{array}{l}\text { SNF-5066, Rev. } 0 \\
\text { Comparison of Toxicological and Radiological Aspects of K Basins Sludge }\end{array}$}} & \multirow{2}{*}{\multicolumn{2}{|c|}{ ECN No. N/A }} \\
\hline & & & & & \\
\hline Name & MSIN & $\begin{array}{c}\text { Text } \\
\text { With All } \\
\text { Attach. }\end{array}$ & Text Only & $\begin{array}{c}\text { Attach./ } \\
\text { Appendix } \\
\text { Only }\end{array}$ & $\begin{array}{c}\text { EDT/ECN } \\
\text { Only }\end{array}$ \\
\hline R. D. Crowe & R3-26 & $\boldsymbol{X}$ & & & \\
\hline R. L. Garrett & R3-26 & $\mathrm{X}$ & & & \\
\hline S. B. Harrington & R3-26 & $\mathbf{X}$ & & & \\
\hline J. C. Lavender & G1-04 & $\mathbf{x}$ & & & \\
\hline C. T. Miller & X3-79 & $\mathrm{X}$ & & & \\
\hline P. D. Rittmann & R3-26 & $\mathbf{X}$ & & & \\
\hline R. H. Webb & R3-26 & $\mathbf{X}$ & & & \\
\hline K Basin Project Files & $X 3-85$ & $\mathbf{X}$ & & & \\
\hline SNF Project Files & R3-11 & $\mathbf{X}$ & & & \\
\hline
\end{tabular}

